\title{
Research Square \\ Exploring the Effects of Climate-related Financial Policies on Carbon Emissions in G20 Countries: A Panel Quantile Regression Approach
}

Paola D'Orazio ( $\sim$ paola.dorazio@rub.de)

Ruhr-Universität Bochum https://orcid.org/0000-0002-3660-2877

Maximilian Dirks

Ruhr-Universität Bochum: Ruhr-Universitat Bochum

\section{Research Article}

Keywords: Financial development, Climate-related financial policies, Carbon Dioxide Emissions, Climate risks, Green finance

Posted Date: May 25th, 2021

DOI: https://doi.org/10.21203/rs.3.rs-476273/v1

License: (c) (i) This work is licensed under a Creative Commons Attribution 4.0 International License.

Read Full License

Version of Record: A version of this preprint was published at Environmental Science and Pollution Research on September 3rd, 2021. See the published version at https://doi.org/10.1007/s11356-021$15655-\mathrm{y}$. 


\title{
ARTICLE \\ Exploring the effects of climate-related financial policies on carbon emissions in G20 countries: a panel quantile regression approach
}

\author{
Paola D'Orazio ${ }^{\mathrm{a}, \mathrm{b}}$ and Maximilian W. Dirks ${ }^{\mathrm{a}}$ \\ ${ }^{a}$ Institute of Macroeconomics, Faculty of Economics and Management, Ruhr-Universität \\ Bochum, Universitätsstraße 150, 44801 Bochum (Germany). \\ ${ }^{b}$ Research Department Closed Carbon Cycle Economy, Ruhr-Universität Bochum, \\ Universitätsstraße 150, 44801 Bochum (Germany).
}

\begin{abstract}
This paper studies the effects of financial development, economic growth, and climate-related financial policies on carbon $\left(\mathrm{CO}_{2}\right)$ emissions for $\mathrm{G} 20$ countries. The focus is on policies implemented to different degrees by G20 countries to scale up green finance and address climate-related financial risks in 2000-2017 and represents this paper's value-added. The empirical results obtained by relying on the panel quantile regression approach indicate that the impacts of the different explanatory variables on carbon emission are heterogeneous. Specifically, the effect of the stock of short-term financial policies on carbon emissions is negative, and its effect becomes smaller at higher quantiles. No significance is reported for the 10th quantile. The stock of long-term policies also show significant negative coefficients, but their impact is stronger for higher quantiles. Financial development contributes to improving environmental quality, and its impact is larger in higher emission countries. Energy consumption increases carbon emissions, with the strongest effects occurring at higher quantiles. Our results also support the validity of the EKC relationship and positive effects of GDP and population on high emissions levels. The study highlights that climate-related financial policies have a negative direct effect on $\mathrm{CO}_{2}$ emissions but a positive indirect effect in some percentiles. This evidence can imply a worsening of environmental quality in high-emission countries when considering the stock of short-term policies and low-emission countries when analyzing the stock of long-term policies. The total effect appears nevertheless negative, which indicates that these policies may improve environmental quality overall in G20 countries.
\end{abstract}

\section{KEYWORDS}

Financial development, Climate-related financial policies, Carbon Dioxide Emissions, Climate risks, Green finance

\section{Introduction}

Global warming has become one of the most severe and pressing issues because of the devastating consequences of environmental degradation on humanity and economic systems globally. The human effect on climate change is also widely reported, and carbon emissions are now considered the highest in history (Nagelkerken and Connell 2015). Carbon dioxide $\left(\mathrm{CO}_{2}\right)$ is the most important greenhouse gas implicated in global warming (Scheffer et al. 2006; Solomon et al. 2009). Its accumulation in the atmosphere 
beyond certain limits can lead to irreversible impacts, which will be challenging to tackle at later stages (IPCC 2014, 2018).

At the international level, several efforts are put forward to mitigate climate change's adverse effects by reducing carbon emissions. The UN Paris Agreement of 2015 set the goal of keeping global warming well below $2^{\circ} \mathrm{C}$ and as close as possible to $1.5^{\circ} \mathrm{C}$ above pre-industrial levels. To comply with this objective, countries should reduce emissions to almost zero by 2050. Nevertheless, the special report of the IPCC (2018) on the global temperature goals shows that the gap between current trends and emissions reduction targets set by countries through their nationally determined contributions (NDCs) is widening and leading to somewhere between $3{ }^{\circ} \mathrm{C}$ and $4{ }^{\circ} \mathrm{C}$ of warming (den Elzen et al. 2019). This scenario is consistent with what has been defined as a "Hothouse Earth" pathway (Steffen et al. 2018). Indeed, the most recent evidence suggests that global carbon emissions have been increasing despite the efforts to reduce them (Peters et al. 2020). In 2020, the International Energy Agency (IEA) reported that global energy-related $\mathrm{CO}_{2}$ emissions flattened in 2019, following two years of increases. According to the analysis, this resulted mainly from a sharp decline in $\mathrm{CO}_{2}$ emissions from the power sector in advanced economies, thanks to the expanding role of renewable sources (primarily wind and solar PV), fuel switching from coal to natural gas, and higher nuclear power output (IEA 2020). However, according to Le Quéré et al. (2019), to limit global warming to below $2^{\circ} \mathrm{C}$ by the year 2100 , greenhouse gas emissions would have to decrease by one to two billion tons every year.

Because of the natural, social and economic disruption it risks generating, the research community from different disciplines has agreed on the compelling need to tackle climate change (Stern et al. 2006; Heller and Zavaleta 2009; Dasgupta 2021). As $\mathrm{CO}_{2}$ is the primary responsible for global warming, the determinants of $\mathrm{CO}_{2}$ emissions have been largely studied in the literature. Among the main drivers, economic growth is usually considered because it promotes economic development and progress. Still, it is detrimental to the environment. Therefore, the literature has investigated the nexus between economic growth and the environment, popularly known as the Environment Kuznets Curve (EKC). Besides the EKC relationship, some researchers focused on the role of democracy and renewable energy in reducing carbon emissions (Adams and Acheampong 2019), others looked at the impact of democracy, globalization and urbanization (Wang et al. 2018), the role played by financial stability and energy consumption (Nasreen et al. 2017). Finally, a broad stream of literature studied the effects of financial development (see Gök 2020, for a recent review). The latter is particularly relevant because both capital markets and the financial sector play a crucial role in delivering the necessary investments in low-carbon technologies to achieve green structural change.

In our view, a closer look at the effects of climate change, the dynamics of $\mathrm{CO}_{2}$ emissions, and the development of financial policies in the past decades suggests the existence of a more complex picture that needs to be investigated. First, the implementation of adaptation and mitigation strategies is related to developing green technologies whose diffusion is constrained by several "barriers", such as costs, lack of competencies and knowledge, market structure, and lack of financial resources (D'Este et al. 2012). The latter is particularly relevant and is motivated by the fact that ecoinnovation requires long-term financial capital, which is, by definition, riskier and, therefore, more expensive than standard "non-green" innovation. Second, although positive trends of green finance development have been detected in the past years, the flow of financial resources is insufficient to close the "green finance gap" (Buchner et al. 2017; IEA 2018; Geddes et al. 2018; D'Orazio and Löwenstein 2020). As a 
result, the existing green finance volumes fall short to meet the $2^{\circ} \mathrm{C}$ scenario called for by IPCC (2018), and a green structural change is difficult to achieve. Overall, this evidence suggests that, when studying the dynamics of carbon dioxide emissions in the past decades, it is essential to account for novel variables. In particular, we claim that it is necessary to include climate-related financial policies (CRFP), which are characterized by two main aims, i.e., to scale up green finance and tackle physical and transition risks for the financial sector (D'Orazio and Popoyan 2019). They are promoted mainly by central banks and financial regulators, whose role in addressing climate-related issues has been at the core of academic and policy discussion in the past years (see Batten et al. 2016; Campiglio et al. 2018, for a review on these topics). Within the context of climate change mitigation, the effect of these policies on $\mathrm{CO}_{2}$ emissions stands out as a complex issue due to different new financial regulations that G20 countries have adopted in the past decades (see Section 4 for a review). However, despite their importance in shaping the climate-related financial landscape, the link between CRFPs and $\mathrm{CO}_{2}$ emissions is still under-investigated (De Haas and Popov 2019).

Against this backdrop, the contribution of this paper to the literature is threefold. First, to the best of our knowledge, CRFPs have not been considered in any empirical analysis of the determinants of $\mathrm{CO}_{2}$ emissions. Our study investigates this issue for the first time and thus provides a primary contribution to understanding their role in affecting environmental quality (proxied by $\mathrm{CO}_{2}$ emissions). Second, this study applies a panel quantile regression (PQR) approach to explore the effect of CRFPs, financial development, and economic growth on the $\mathrm{CO}_{2}$ emissions. Applying the PQR approach will allow us to provide more detailed results than the standard ordinary least squares (OLS) approach and discuss the heterogeneity characterizing countries' experiences. Third, the study's focus on G20 countries is important because they represent the leading global economies and offer a broad sample of developed and developing countries. Furthermore, they are the most significant contributors to global carbon emissions. Hence, we deem it relevant to study the role of CRFP from the G20 perspective.

The remainder of the paper is organized as follows. Section 2 offers a review of the literature and puts our study in context. The methodology is presented in section 3 and data are described in section 4 . Section 5 provides the empirical results and discussions, and, finally, section 6 offers concluding remarks and discusses policy implications of the investigation.

\section{Literature review}

\subsection{Economic growth, financial development and environmental quality}

After the seminal contribution by Grossman and Krueger (1995), academic research has focused on the effects of growth on $\mathrm{CO}_{2}$ emissions. The relationship between the measure of environmental degradation, i.e., $\mathrm{CO}_{2}$ emissions, and per capita income is defined as the Environmental Kuznets Curve (EKC). The EKC hypothesis states that an inverted U-shaped relationship between environmental degradation and economic growth exists. It is maintained that environmental degradation increases at the initial stage of economic growth; as the economy grows, environmental degradation falls, and environmental quality improves. The evidence on the EKC is, however, still mixed. According to some researchers, the EKC relationship is not valid because it is observed 
that environmental degradation is monotonically increasing with economic growth (see Stern 2004; Alkhathlan and Javid 2013; Farhani and Ozturk 2015, among others). Others find instead support for the EKC hypothesis (see He and Richard 2010; Apergis and Payne 2010; Apergis and Ozturk 2015; Jebli et al. 2016, among others). Therefore, it is essential to test the ECK hypothesis's validity when designing appropriate policy tools to fight against global warming and protect the environment.

Moreover, when discussing the relationship between economic growth and $\mathrm{CO}_{2}$ emissions, it is important to consider financial development. The rationale for this is that financial development enhances economic growth, which requires, among others, more energy consumption, resulting in pollution and environmental degradation. While financial development is claimed to have significant implications for the environment, its impact on carbon emissions remains contentious.

Two main opposing views about the impact of financial development on the environment can be distinguished. Some scholars believe that financial development improves the environment's quality by reducing carbon emissions. They argue that financial development can facilitate more financial resources at a lower cost, thus increasing financing for environmental projects (see Tamazian et al. 2009; Acheampong 2019, among others), and that financial development may provide enough incentives for firms to lower their $\mathrm{CO}_{2}$ emissions (Lanoie and Roy 1997; Dasgupta et al. 2001). Some researchers also maintain that financial development provides developing countries with more opportunities for advanced technologies, which implies increased energy efficiency and sustainable and environmentally-friendly production, thus reducing $\mathrm{CO}_{2}$ emissions (Claessens and Feijen 2007). According to others, financial development contributes instead to environmental degradation. It increases households' consumption and firms' production and accelerates economic growth, resulting in polluting activities and thereby causes an increase in emissions. Zhang (2011) found that financial development is one of the factors responsible for increasing the level of $\mathrm{CO}_{2}$ emissions. Financial development also contributes to a rise in energy consumption and $\mathrm{CO}_{2}$ emissions in Sub-Saharan African countries, as discussed in Al-Mulali et al. (2012). As noted by Gök (2020), the difference in the estimated effect depends on the financial development indicator used (see Acheampong 2019, on this point), the econometric technique employed, selected countries, country group, region, or provinces involved, and time span considered in the investigation.

Overall, by considering the literature published so far on the role of financial development on $\mathrm{CO}_{2}$ emissions, it seems that different impacts are observed for different countries or groups of countries (Gök 2020). On the one hand, studies considering African countries or focusing on individual countries such as Brazil, Greece, India, Indonesia, Nigeria, Pakistan, Portugal, Saudi Arabia, Sri Lanka, Tunisia, Turkey, USA, and Vietnam tend to report a significant positive impact on the effect of financial development on $\mathrm{CO}_{2}$ emission. On the other hand, studies analyzing emerging markets, Asia, Commonwealth of Independent States (CIS), European Union (Park et al. 2018), Gulf Cooperation Council (GCC), Next 11, APEC (Zaidi et al. 2019) and OECD countries (Lee et al. 2015) or focusing on individual countries such as Bangladesh (Khan et al. 2018), China, Iran, Malaysia and Russia tend to report a significant negative impact on the effect of financial development on $\mathrm{CO}_{2}$ emission. 


\subsection{Green financial development: climate-related financial policies and environmental quality}

Although central banks and financial regulators cannot substitute for an adequate climate policy (Lane 2019; Weidmann 2020), it is now widely acknowledged that they have to take action to scale-up green finance and adopt regulations to address climaterelated financial risks. The rationale for this is that (i) climate change affects monetary policy and financial regulation (Batten et al. 2016; Campiglio 2016; D'Orazio and Popoyan 2019; Chenet et al. 2021) and (ii) financial actors play an essential role in the global economy (Rogoff 1999; Wang 2017; Geddes et al. 2018; Mazzucato and Semieniuk 2018).

Central banks and financial regulators have been particularly engaged in climaterelated financial policymaking in the past decades. Regarding their green finance action, they can redirect financial flows towards activities that protect natural capital and positively affect the environment (Galaz et al. 2015). This policy action is also aligned to the Paris Agreement goal (Article 2.1c) of "making finance flows consistent with a pathway towards low greenhouse gas emissions and climate-resilient development" (COP 2015). Compared with traditional finance, green finance emphasizes environmental interests; it regards environmental protection and the effective use of resources as important criteria for measuring the effectiveness and ultimately realizes sustainable development and promotes economic growth (Yadav and Pathak 2013; Steckel et al. 2017; Sachs et al. 2019). Therefore, like financial development, the development of green finance can also promote economic growth. Regarding action taken against climate risks, their effort is crucial as climate change poses threats to the conduct of monetary policy because of its effects on supply price shocks, market volatility, and economic growth, which are related to inflation through credit spreads, saving rates, and real interest rates (Coeuré 2018; Monnin 2018; Schnabel 2020). Moreover, climaterelated financial risks (CRFRs), namely, physical, transition, and liability risks, represent a threat to financial stability (Carney 2015). CRFRs can cause credit risks, market risks, liquidity risks, and insurance risks because of financial losses, destruction of production capital, decline in profitability of exposed firms, and stranding of assets related to climate-relevant sectors (e.g., fossil fuels and mining) (Batten et al. 2016; Elderson 2018). Central banks and regulators are thus required to assess financial institutions' performance and report how they account for environmental and social issues and provide guidance and requirements regarding how financial institutions impact ecosystems (Carney 2015; Scholtens 2017; HLEG 2018; ECB 2020).

Several policies are suitable for scaling up green finance and address climate risks, thus contributing to the decarbonization and low-carbon transition (D'Orazio and Popoyan 2019). We define them as climate-related financial policies (CRFPs) throughout the paper, and we distinguish among four categories; namely (i) climate-related prudential regulations; i.e., measures such as governance and risk management measures, climate-related stress tests and climate-related risk disclosure aimed at the banking sector (ii) promotional credit measures; (iii) green financial principles; i.e., policies aimed at "creating green financial markets", such as green finance principles and green taxonomy and (iv) other climate-related disclosure requirements aimed at non-financial institutions, insurance companies and pension funds.

In the first category, several prudential measures existing under the Basel III framework can be used to meet the Paris Agreement goals (see D'Orazio and Popoyan 2019, for a review). Among others, leverage ratios, countercyclical capital buffers, and risk weights applied to banks' assets, such as the Green Supporting Factor (GSF) or the 
Brown Penalising Factor (Schoenmaker and Van Tilburg 2016), could be implemented. Following the proposal of a GSF by the European Commission (Dombrovskis 2017), green capital regulations have been discussed in the past years, with many analyses pointing to significant risks deriving from its potential implementation. Among others, threats to financial stability are emphasized, considering that green assets are not risk-free. Sectoral leverage ratios could also be implemented to limit the financial sector's exposure to brown assets, thus addressing potential threats from a low-carbon transition. Other measures relate to climate-related stress tests ${ }^{1}$ that provide useful information to policymakers regarding the financial system exposure to climate-related risks (see, e.g., Vermeulen et al. 2019) and their results could be used to calibrate and evaluate green macroprudential tools. Other (banking) prudential measures, such as disclosure requirements of the physical, liability and transition risks associated with climate change, are also relevant to develop a credible green financial system and avoid the so-called 'green washing' (TCFD 2018).

Central banks can also directly promote green-sustainable investments through promotional credit measures, such as green lending quotas and concessional loans to priority and environmentally friendly sectors.

Sustainability reporting and compliance practices are increasingly considered complementary to risk management practices in dealing with concerns about the adverse consequences of climate change ( $\mathrm{Ng} 2018$ ). Accordingly, the fourth category concerns reporting regulations and environmental, social, and governance (ESG) criteria aimed at pension funds, insurance companies, and other non-financial institutions. Reporting regulations on pension funds have become prominent in the debate on the importance of climate risks for institutional investors (Della Croce et al. 2011) and on how to tackle climate change from the financial sector perspective (see Ameli et al. 2019, among others). In particular, after the Paris Agreement, a better understanding of whether institutional investors' portfolios are exposed to asset stranding and, consequently, financial risks has become increasingly important for investors, regulators, and the economy at large (Boermans and Galema 2019; Krueger et al. 2020). Regarding ESG criteria, they have been gathering much consideration, both in the economics profession and among policymakers (Wang and Sarkis 2017; Lokuwaduge and Heenetigala 2017; Li et al. 2018; Widyawati 2020). Indeed, ESG metrics and their implementation have become a critical part of business strategy. Although there are risks of greenwashing (Yu et al. 2020), ESG disclosure is becoming relevant because it is found to have positive effects on firms' performance, besides reducing uncertainty, business risk, and the cost of capital (El Ghoul et al. 2011; Amel-Zadeh and Serafeim 2018; Bhaskaran et al. 2020).

\section{Method}

\subsection{Panel quantile regression}

The econometric model specification involves the use of the Method of Moments Quantile Regression (MMQR) developed by Machado and Silva (2019). This choice is motivated by the fact that this method allows us to identify the conditional heterogeneous covariance effects of the determinants of $\mathrm{CO}_{2}$ emissions. More precisely, the method

\footnotetext{
${ }^{1}$ They aim at assessing the resilience of the financial system to adverse climate shocks by considering the possible impact of hypothetical climate-related shock scenarios on the stability of individual financial institutions and the financial system in its complexity (NGFS 2019).
} 
developed by Machado and Silva (2019) allows the individual effects to affect the entire distribution, rather than being just locations (means) shifters, as in the case of Koenker (2004). Moreover, the MMQR estimation technique is particularly relevant in scenarios where the panel data model is embedded with individual effects, as in the case of our analysis.

The estimation of the conditional quantiles $Q_{Y}(\tau \mid X)$ for a model of the location/scale variant of quantile regression takes the following form:

$$
Y_{i t}=\alpha_{i}+X_{i t}^{\prime} \beta+\left(\delta_{i}+Z_{i t}^{\prime} \gamma\right) U_{i t}
$$

where the probability $P\left\{\delta_{i}+Z_{i t}^{\prime} \gamma>0\right\}=1 .\left(\alpha, \beta^{\prime}, \delta, \gamma^{\prime}\right)^{\prime}$ are parameters to be estimated. In particular, $\left(\alpha_{i}, \delta_{i}\right), i=1, \ldots, n$ designates the individual $i$ fixed effects and $Z$ is a k-vector of identified components of $X$ which are differentiable transformations with elements $l$ given by

$$
Z_{l}=Z_{l}(X), l=a, \ldots, k
$$

$X_{i t}$ is independently and identically distributed for any fixed $i$ and is independent across time $t . U_{i t}$ is independently and identically distributed across individuals $i$ and through time $t$ and are orthogonal to $X_{i t}$ and normalised to satisfy the moment conditions in Machado and Silva (2019). Equation 1 implies

$$
Q_{Y}(\tau \mid X)=\left(\alpha_{i}+\delta_{i} q(\tau)\right)+X_{i t}^{\prime} \beta+Z_{i t}^{\prime} \gamma q(\tau)
$$

$Q_{Y}(\tau \mid X)$ indicates the quantile distribution of the dependent variable $Y_{i t}$, that in our case is the logarithm of $\mathrm{CO}_{2}$ emissions per capita and is conditional on the location of independent variable $X_{i t} . \alpha_{i}+\delta_{i} q(\tau)$ is the scalar coefficient which is indicative of the quantile- $\tau$ fixed effect for individual $i$. It is important to note that the individual effect in this context does not denote an intercept shift, but they are time-invariant parameters whose heterogeneous impact are allowed to differ across the quantiles of the conditional distribution of the endogenous variable $Y . q(\tau)$ denotes the $\tau$-th sample quantile which is estimated by solving the following optimization problem

$$
\min _{q} \sum_{i} \sum_{t} \rho_{\tau}\left(R_{i t}-\left(\delta_{i}+Z_{i t}^{\prime} \gamma\right) q\right)
$$

where $\rho_{\tau}(A)$ denotes the check function.

In Equation 3, $X_{i t}^{\prime}$ is a vector of independent variables as specified in Equation 5.

$$
\begin{aligned}
Q_{C O 2_{i t}}\left(\tau_{k} \mid \alpha_{i} x_{i t}\right)= & \left(\alpha_{i}+\delta_{i} q(\tau)\right)+\beta_{1 \tau} G D P_{i t}+\beta_{2 \tau} G D P_{i t}^{2}+\beta_{3 \tau} \text { Pop }_{i t} \\
& +\beta_{4 \tau} L T F P_{i t}+\beta_{5 \tau} S T F P_{i t}+\beta_{6 \tau} \text { Domcredit }_{i t}+\beta_{7 \tau} \text { ChinnIto }_{i t} \\
& +\beta_{8 \tau} R O A_{i t}+\beta_{9 \tau} F F C_{i t}+Z_{i t}^{\prime} \gamma q(\tau)
\end{aligned}
$$

where GDP denotes Gross Domestic Product in country $i$ in period $t$ and Pop is the population size. LTF P represents long-term financial policies, whereas short-term financial policies are labelled as $S T F P$. Domestic credit, Chinn-Ito Index for financial openness, return on assets and fossil fuel consumption are denoted with Domcredit, 
ChinnIto, ROA and FFC, respectively. Details about the description and source of variables are reported in Section 4.

\subsection{The effect of climate-related financial policies on $\mathrm{CO}_{2}$ emissions}

To estimate the direct and indirect effect of CRFPs on $\mathrm{CO}_{2}$ emissions in $\mathrm{G} 20$ countries, we develop the following two equations. Equation 6 defines pollution as a function of income, population, short-term and long-term green policies, and other factors. Equation 7 defines income as a function of lagged income, short-term and long-term green policies, and other explanatory variables, such as total consumption, public spending and investment and net exports.

$$
\begin{array}{r}
C O 2_{i t}=\alpha_{i}+\beta_{1 \tau} G D P_{i t}+\beta_{2 \tau} G D P_{i t}^{2}+\beta_{3 \tau} \text { Pop }_{i t}+\beta_{4 \tau} L T F P_{i t}+\beta_{5 \tau} S T F P_{i t} \\
+\beta_{6 \tau} \text { Domcredit }_{i t}+\beta_{7 \tau} \text { ChinnIto }_{i t}+\beta_{8 \tau} R O A_{i t}+\beta_{9 \tau} F F C_{i t}+\epsilon_{i t} \\
\widehat{G D P}_{i t}=\alpha_{i}+G D P_{i t-1}+K_{i t}+\pi_{i t}+\text { Pop }_{i t}+L T F P_{i t}+S T F T_{i t}+\mu_{i t}
\end{array}
$$

where $\widehat{G D P}$ represents the estimated GDP in billion US-Dollar, $K$ denotes the gross capital formation in percent of GDP, and $\pi$ is the inflation rate. The population size is denoted with Pop. The subscript $i$ represent the country, while $t$ denotes the year; $\epsilon_{i t}$ and $\mu_{i t}$ represent the error terms.

We then apply the Two-Stage Least Squares method (Kelejian 1971) to estimate direct, indirect and total effect by considering the whole $\mathrm{CO}_{2}$ distribution. The direct effects are calculated by estimating equation 6 . More precisely, the coefficient size of $\beta_{4 \tau}$ and $\beta_{5 \tau}$ corresponds to the direct effect of the LTFPs and STFPs on $\mathrm{CO}_{2}$ emissions. In a second step, the estimated $\widehat{G D P}_{i t}$ is used to reestimate equation 6 . The coefficients obtained with $\widehat{G D P}_{i t}$ instead of $G D P_{i t}$ correspond to the total effect of LTFPs and STFPs. The indirect effects are equal to the difference between total effects and direct effects.

\section{Data}

The following section presents the variables used in the empirical analysis. Their description and sources are summarized in Table 1 and summary statistics are provided in Table 2. Among others, we note that all variables are skewed; this represents another motivation for employing the quantile regression approach to detect the effect of climate-related financial policies on $\mathrm{CO}_{2}$ emissions in this paper.

The sample considered in our investigation includes G20 countries, except the European Union, which was excluded because of the unavailability of data for several variables considered in the analysis. The choice to focus on G20 countries is motivated by the fact that they represent the leading global economies and offer a broad sample of developed and developing countries. Furthermore, they are the most significant contributors to global carbon emissions.

The correlation matrix of the data presented in Table 3 shows a positive relationship between GDP and $\mathrm{CO}_{2}$ emissions, population and GDP, fossil fuels consumption and 


\begin{tabular}{lll}
\hline \hline Variable & Abbreviation & Source \\
\hline $\mathrm{CO}_{2}$ Emissions in metric tons in million & $\mathrm{CO}_{2}$ & Hannah Ritchie and Max Roser (2020) \\
GDP (in billion current US-Dollar) & GDP & World Bank, World Development Indicators \\
Squared GDP (in billion current US-Dollar) & GDP2 & World Bank, World Development Indicators \\
Population, in million & Pop & World Bank, World Development Indicators \\
Regulatory quality & RQ & World Bank, World Governance Indicators \\
Long-term financial policies & LTFP & Individual Assessment, public available information from official sources \\
Short-term financial policies & STFP & Individual Assessment, public available information from official sources \\
Domestic credit to private sector (share of GDP) & Domcredit & World Bank, Global Financial Development Database \\
Chinn-Ito index & ChinnIto & Chinn and Ito (2010) \\
Bank Return On Assets (Percentages, After Tax) & ROA & World Bank, Global Financial Development Database \\
Fossil fuel consumption in TWH per capita & FFC & World Bank based on IEA Statistics \\
\hline \hline
\end{tabular}

Table 1.: Variables definitions and data sources. All data are annual over the period 2000-2017.

\begin{tabular}{|c|c|c|c|c|c|c|c|}
\hline Variable & Mean & Std. Dev. & Min. & Max. & Skewness & Kurtosis & $\overline{\mathrm{N}}$ \\
\hline CO2 Emissions in metric tons in million & 1244.389 & 1915.701 & 124.381 & 9599.007 & 2.81326 & 10.33977 & 342 \\
\hline GDP (in billion current US-Dollar) & 2425.476 & 3426.546 & 97.724 & 19519.354 & 2.973936 & 11.94385 & 342 \\
\hline Squared GDP (in billion current US-Dollar) & $1.76 \mathrm{e}+07$ & $5.42 \mathrm{e}+07$ & 9549 & $3.81 \mathrm{e}+08$ & 4.339691 & 22.61093 & 342 \\
\hline Population, in million & 221.536 & 367.277 & 19.153 & 1386.395 & 2.419018 & 7.239013 & 342 \\
\hline Long-term financial policies weighted by regulatory quality & 0.698 & 1.727 & -2.605 & 10.732 & 2.604342 & 11.9387 & 342 \\
\hline Short-term financial policies weighted by regulatory quality & 0.068 & 0.408 & -0.475 & 3.521 & 6.463013 & 48.43763 & 342 \\
\hline Domestic credit to private sector (share of GDP) & 90.174 & 53.284 & 9.683 & 212.269 & .2269743 & 1.882335 & 312 \\
\hline Chinn-Ito index & 0.835 & 1.43 & -1.917 & 2.347 & -.3234056 & 1.607863 & 342 \\
\hline Bank Return On Assets (Percentages, After Tax) & 0.984 & 1.07 & -6.697 & 6.843 & -.860239 & 14.81627 & 342 \\
\hline Fossil fuel consumption in TWH per capita & 35.463 & 23.907 & 3.221 & 94.873 & .6237114 & 2.342099 & 342 \\
\hline
\end{tabular}

Table 2.: Summary statistics of variables

\begin{tabular}{|c|c|c|c|c|c|c|c|c|c|c|}
\hline Variables & 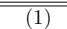 & (2) & (3) & (4) & (5) & (6) & (7) & (8) & (9) & 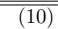 \\
\hline $\mathrm{CO}_{2}$ Emissions in metric tons in million & 1.000 & & & & & & & & & \\
\hline GDP (in billion current US-Dollar) & 0.764 & 1.000 & & & & & & & & \\
\hline Squared GDP (in billion current US-Dollar) & 0.677 & 0.950 & 1.000 & & & & & & & \\
\hline Population, in million & 0.667 & 0.249 & 0.181 & 1.000 & & & & & & \\
\hline Stock of long-term financial policies weighted by regulatory quality & -0.152 & 0.086 & 0.048 & -0.253 & 1.000 & & & & & \\
\hline Stock of short-term financial policies weighted by regulatory quality & -0.081 & -0.004 & -0.039 & -0.090 & -0.067 & 1.000 & & & & \\
\hline Domestic credit to private sector (share of GDP) & 0.403 & 0.588 & 0.484 & 0.009 & 0.289 & 0.080 & 1.000 & & & \\
\hline Chinn-Ito index & -0.116 & 0.307 & 0.211 & -0.472 & 0.410 & 0.183 & 0.396 & 1.000 & & \\
\hline Bank Return On Assets (Percentages, After Tax) & -0.017 & -0.131 & -0.039 & -0.014 & -0.201 & -0.078 & -0.371 & -0.298 & 1.000 & \\
\hline Fossil fuel consumption in TWH per capita & 0.111 & 0.290 & 0.303 & -0.365 & 0.230 & 0.022 & 0.378 & 0.513 & 0.016 & 1.000 \\
\hline
\end{tabular}

Table 3.: Cross-correlation table of variables

$\mathrm{CO}_{2}$ emissions. The outcomes also reveal positive co-movement of GDP and fossil fuels consumption and domestic credit to the private sector and GDP. A negative correlation is observed for both the long-term and short-term stock of policies and $\mathrm{CO}_{2}$ emissions.

\subsection{Dependent variable}

As the dependent variable, we consider total $\mathrm{CO}_{2}$ emissions (in million metric tons) deriving from fossil fuels' consumption, i.e., coal, natural gas, and oil and cement. Because $\mathrm{CO}_{2}$ is reported to be the primary greenhouse gas responsible for global warming, we use it as an environmental degradation measure. We collected data from the " $\mathrm{CO}_{2}$ and Greenhouse Gas Emissions" database, which uses data from Le Quéré et al. (2018) and provides the latest available data (2017) regarding $\mathrm{CO}_{2}$ emissions at the G20 level.

The heterogeneity concerning the $\mathrm{CO}_{2}$ distribution in our sample is shown in Figure 1, which allows us to visualize the countries that belong to the lowest and highest quantiles. Summary statistics reported in Table 2 show that the distribution of $\mathrm{CO}_{2}$ emissions is positively skewed. 


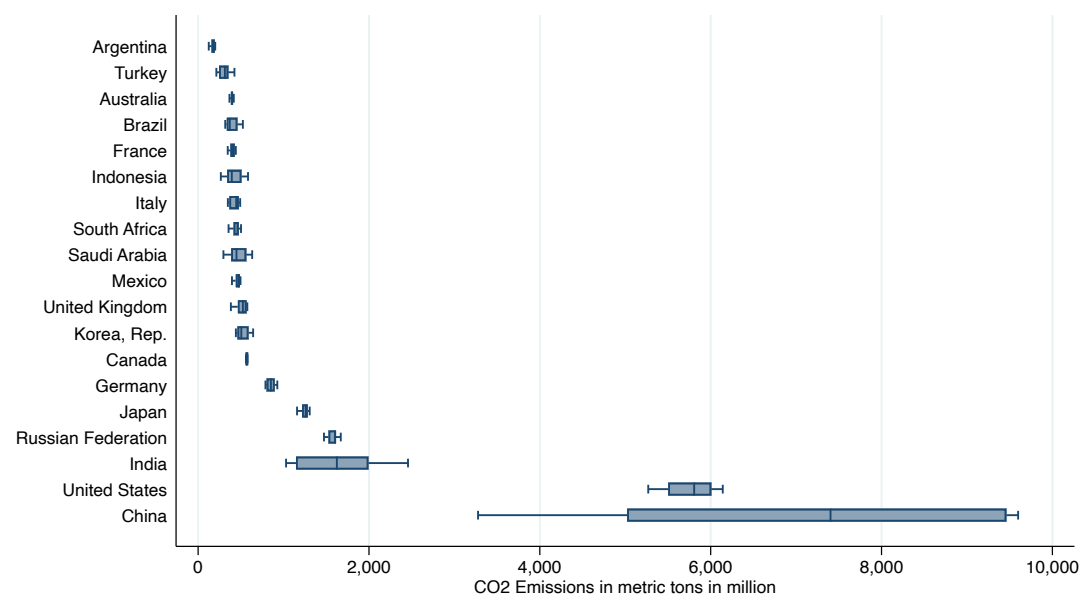

Figure 1.: Distribution of $\mathrm{CO}_{2}$ emissions by country (2000-2017).

\subsection{Climate-related financial policies in the G20}

Using the taxonomy presented in Section 2.2, we surveyed official documents by central banks, financial supervisory authorities, governments, and banking associations and found 93 policies adopted by G20 countries, as described in Anonymized (2021). Consequently, our CRFP data constitutes a panel of 342 country-year observations (as we consider 19 countries over 18 years).

As shown in Figure 2 and Table 4, all G20 countries - although to different degrees - have acknowledged the need to adjust national financial architectures and are discussing, or have already implemented, green financial principles, such as national green finance strategies, climate-related financial risks, and taxonomy of green and brown investments. In particular, our data show that a steady increase over time characterizes the adoption of CRFPs. The rationale for this is that, on the one hand, countries increasingly recognize that climate-related risks such as transition, liability, and physical risks may harm the financial system and financial stability in general; hence, central banks and financial regulators are considering how to integrate them into existing regulatory frameworks (Carney 2015; Thoma and Chenet 2016; Volz 2017; NGFS 2019; D'Orazio and Popoyan 2019). On the other hand, the financial sector's role in enhancing a low carbon transition by providing adequate financial resources to scale up green finance has got increasing attention in the past decades (Wang and Zhi 2016; Sachs et al. 2019; Hafner et al. 2020).

According to our data, some G20 countries such as UK and France, have been engaged in green finance policymaking since the early 2000s, with the adoption of green finance principles and climate-related disclosure requirements for non-financial institutions, pension funds, and insurance companies ${ }^{2}$. Indonesia stands as the earliest adopter of CRFPs; already in 1998, it started to require banks to conduct environmental impact assessments for large or high-risk loans (GoI 1998), while China and Brazil rise as the most engaged G20 countries in climate-related financial policymaking; at the end of 2017, they have both 11 policies. China adopted measures explicitly aimed at

\footnotetext{
${ }^{2}$ European Central Bank (ECB) is also showing a progressively increasing commitment to "greening the financial system" by announcing the goal to make climate change a "mission-critical" priority (FT 2020). Moreover, it emphasizes that banks lag on their climate-related and environmental risk disclosures, despite some improvement since 2019 (ECB 2020).
} 
governance and risk management, such as the Green Credit Policy approved in $2007^{3}$. Moreover, it encourages climate-related stress testing (CRST) at the portfolio level since 2012 with the Green Credit Guidelines ${ }^{4}$. Brazil, instead, promotes sustainable development through lines of credit and programs since 2008. These policies aim to foster the population's standards of living and environmental protection (Berchin et al. 2018). Other policies implemented in Brazil are Resolution 4.327/2014, which legally mandates that financial institutions develop and implement a social and environmental policy, and sustainability risk management and ESG disclosures. Moreover, the Brazilian central bank (BaCen) requires that financial institutions demonstrate how they are assessing the risk of exposure to socio-environmental damages in their assessment processes and in their calculation of the capital needed for dealing with risks ${ }^{5}$. Climate-related disclosure requirements for banks have been promoted by the Chinese macroprudential authority, the Indonesian central bank, Turkey's and Mexico's banking associations. Instead, climate-related disclosure requirements for non-financial institutions, pension funds, insurance companies, and 'green' finance principles and guidelines have been widely adopted in the past 20 years in most G20 countries. These measures aim not to be macroprudential but to create a financial market aligned with climate change concerns. Notably, China, which represents a very engaged country in green finance and financial regulation, is the only jurisdiction among the G20s that has adopted differentiated reserve requirements. Finally, we note that all countries except Saudi Arabia have developed green market-shaping policies and adopted disclosure requirements for non-financial firms, insurance companies or institutional investors.

Regarding credit allocation to priority and environmentally friendly sectors, such as green lending quotas and concessional loans, we found that they are adopted mainly by emerging economies, namely, Brazil, China, India, and Indonesia. Among developed countries, two exceptions are represented by $\operatorname{Japan}^{6}$ and South Korea ${ }^{7}$.

To account for lags between the date of adoption and the effects created by the policies, we aggregate the annual impact of climate-related financial policies in two different variables, i.e., the stock of short-term policies (STFP) and the stock of longterm policies (LTFP) ${ }^{8}$. The first refers to policies adopted between 2016 and 2017, while the latter refers to policies adopted between 2000 and 2015. Both variables are then multiplied by the time-varying World Governance Indicator for Regulatory Quality from the World Bank database (Kaufmann et al. 2011) to account for the role played by institutional governance. This allows us to model the evidence that financial policies that are implemented in countries with a higher ability to formulate and implement sound policies and regulation are more effective.

\footnotetext{
${ }^{3}$ It recommends banks to include environmental compliance and environmental risk assessment in the loan origination process (Wang et al. 2019; Xing et al. 2020).

${ }^{4}$ The Network for Greening the Financial Sector (NGFS) gave an additional impulse to this trend in 2019, leading several of its members to incorporate socially responsible investing in their portfolio management and reviewing their operations (NGFS 2017, 2019). The UK government and regulators, the Central Bank of the Netherland, and the Banque de France, among others, have lately shown strong leadership in this area (Carney 2015; DNB 2017; Batten et al. 2016; Campiglio et al. 2018) and planned to conduct CRST in upcoming years. ${ }^{5}$ See Brazilian Circular on Internal Process of Capital Adequacy Assessment, No. 3,547/2011.

${ }^{6}$ In 2010, the Bank of Japan launched the Loan Supporting program consisting of concessional loans for priority sectors (i.e., environment and energy business).

${ }^{7}$ In 2017, the Shinhan Bank launched its 'Green Management Firm Loan Program' with the South Korean Ministry of Environment and KEITI, a UNEP FI Supporting Institution. The program aims at promoting Eco-friendly Small and Medium Enterprises, and loans are created with a lower interest rate.

${ }^{8} \mathrm{~A}$ similar approach has been developed in Eskander and Fankhauser (2020) to study the impact of national climate legislation on the reduction of GHG emissions.
} 

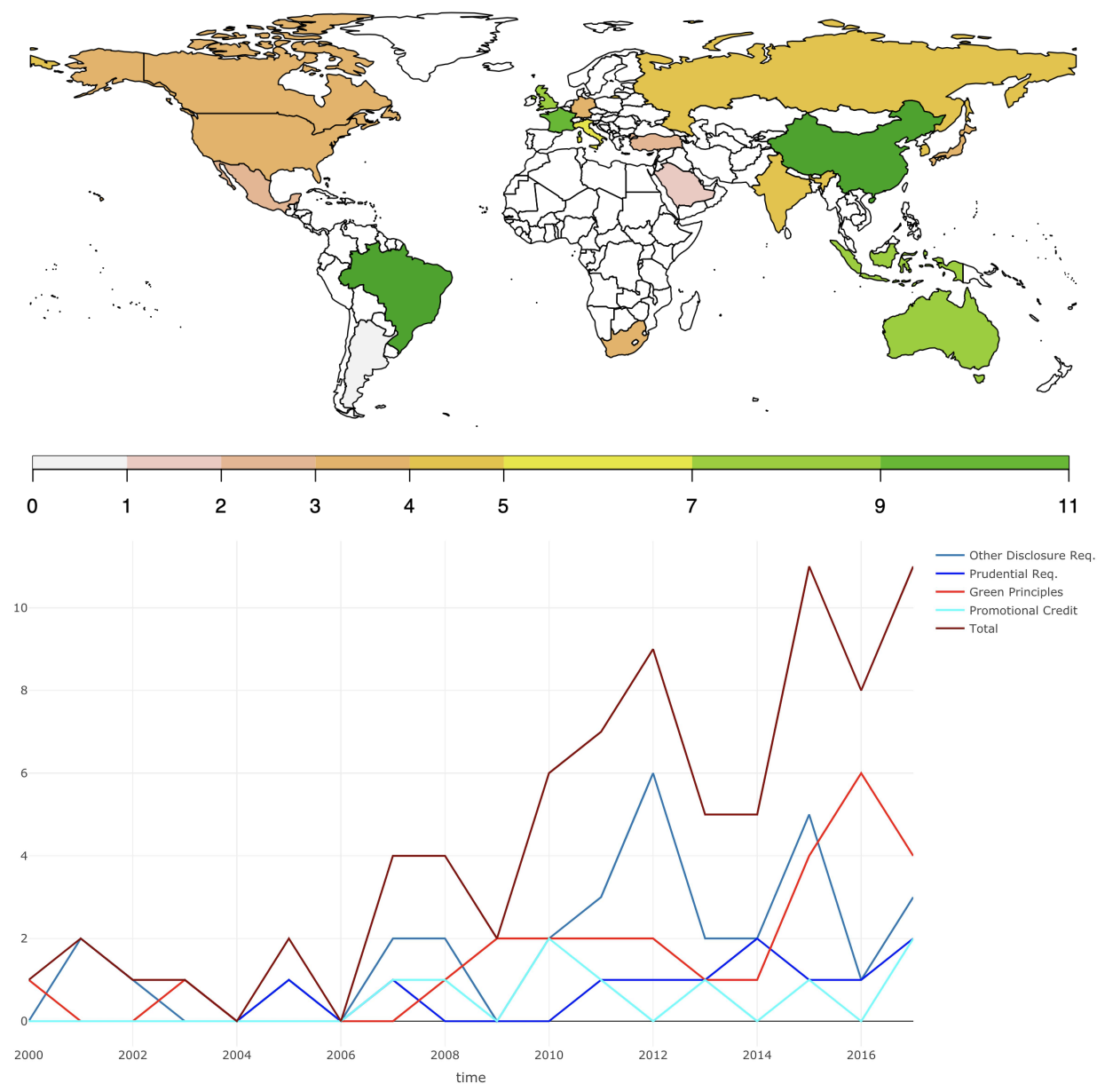

Figure 2.: Stock of climate-related financial policies adopted by country at the end of 2017 (top graph). Number of climate-related financial policies adopted per year during 2000-2017 in G20 (bottom graph). Source: authors' elaboration on data retrieved from Anonymized (2021). 


\begin{tabular}{lcccc} 
Country & $\begin{array}{c}\text { Macroprudential } \\
\text { regulations }\end{array}$ & $\begin{array}{c}\text { Other disclosure } \\
\text { requirements }\end{array}$ & $\begin{array}{c}\text { Promotional } \\
\text { credit measures }\end{array}$ & $\begin{array}{c}\text { Green Financial } \\
\text { Principles }\end{array}$ \\
\hline Argentina & GRM & $\checkmark$ & $\checkmark$ & $\checkmark$ \\
Australia & ICAAP & $\checkmark$ & $\checkmark$ & $\checkmark$ \\
Brazil & GRM, CRST, DR, RR & $\checkmark$ & & $\checkmark$ \\
Canada & GRM & $\checkmark$ & $\checkmark$ & $\checkmark$ \\
China & & $\checkmark$ & $\checkmark$ & $\checkmark$ \\
France & GRM, DR & $\checkmark$ & $\checkmark$ & $\checkmark$ \\
Germany & & $\checkmark$ & $\checkmark$ \\
India & GRM, DR & $\checkmark$ & & $\checkmark$ \\
Indonesia & & $\checkmark$ & & $\checkmark$ \\
Italy & GRM & & $\checkmark$ & $\checkmark$ \\
Mexico & & $\checkmark$ & & $\checkmark$ \\
$\begin{array}{l}\text { Russian Federation } \\
\text { Saudi Arabia }\end{array}$ & & & & $\checkmark$ \\
South Africa & & $\checkmark$ & & $\checkmark$ \\
South Korea & GRM, DR & $\checkmark$ & & $\checkmark$ \\
United Kingdom & & & & $\checkmark$ \\
United States of America & & & & \\
\hline
\end{tabular}

Table 4.: Type of policies adopted by country at the end of 2017. Legend: GRM: Governance and risk management, CRST: Climate-related stress test, DR: Disclosure requirements, RR: Reserve requirements. Source: authors' elaboration on data retrieved from Anonymized (2021).

\section{3. $\quad$ Other variables}

The statistical model is completed by a set of control variables on economic factors, financial development and financial stability. Regarding the former, GDP controls for the possibility of an environmental Kuznets curve (Stern 2004) and population controls for changes in the countries' structure that may affect the emissions profile (Meyerson 1998). Both variables are retrieved from the World Bank's World Development Indicators database. Summary statistics show that the sample is very heterogeneous concerning these variables. Differences in GDP are relatively high and similar to $\mathrm{CO}_{2}$ emissions distribution; it shows a positive skewness and high kurtosis. Fossil fuel consumption (TWH per capita) data are retrieved from the World Bank database. This variable serves as an indicator of the economy's climate footprint since fossil energy consumption is a major source of environmental degradation as it contributes to polluting emissions (Meyerson 1998; Zhou and Feng 2017; Peters et al. 2020). The highest fossil fuel consumption can be observed in the US, Saudi-Arabia and Canada. In contrast, less advanced economies like Indonesia and India tend to consume fewer fossil fuels per capita. However, since energy consumption and economic growth alone may not explain $\mathrm{CO}_{2}$ emissions, we need to consider other variables associated with carbon emissions. Therefore, we also include variables related to financial development, openness and efficiency.

Domestic credit to the private sector (as a share of GDP) is employed to account for the development of the financial industry; the higher the value of this indicator, the more mature the financial system. The choice to include domestic credit to the private sector is related to the evidence that economic development is a complex process that causes a structural change in the economy. In turn, a significant structural change that accompanies economic development is the financial sector's size and structure.

Return on assets (ROA) is considered to account for the banking system's profitability and efficiency, as ROA is a good proxy for the financial system's soundness. A high value indicates profitability and efficiency, as the banks' profits should reduce the extent of risk in the financial market; a low value indicates the banking sector's 
fragility. Overall, a better-developed financial system is believed to increase economic efficiency (Fase and Abma 2003; Sahay et al. 2015) which in turn could be associated with environmental degradation.

Finally, to control the effects of financial openness, the Chinn-Ito Index (or Kaopen index) is used (Chinn and Ito 2010) ${ }^{9}$. It is one of the most commonly used indices in the literature (Ozturk and Acaravci 2013; You et al. 2015; Rasoulinezhad and Saboori 2018) and is constructed based on the data from the IMF Annual Report on Exchange Arrangements and Exchange Restrictions. It ranges between -2.66 (full capital controls) and 2.66 (complete liberalization).

\section{Empirical results and discussions}

\subsection{Diagnostics}

Before estimating the model, some standard preliminary tests are performed to ensure the time-series properties of the selected variables.

First, we check the stationary properties for all variables in this paper and the detailed results of the ADF test are reported in Table 5. The null hypothesis following an $\mathrm{AR}(1)$ or $\mathrm{AR}(3)$ process cannot be rejected in almost all cases in levels. Hence, regression results may be biased due to a spurious relationship. The use of first differences would solve this problem, but we note that the long-term relationship between the variables would be lost.

Second, to control if a spurious relationship biases the regression results, cointegration tests are applied. The Pedroni (2004), Kao (1999) and Westerlund (2007) cointegration test results are displayed in Table 6 . In general, the test results provide robust support for cointegration. Therefore, the analysis considers data in levels.

Third, we check the existence of cross-sectional dependence (CD) within the panel, as it can distort the true parameter values of coefficient estimates. CD may arise due to unobserved common factors; if ignored, it can diminish panel data efficiency gains (Phillips and Sul 2003). To produce robust estimation, the Pesaran (2004) CD test is thus applied; results are reported in Table 7. The null hypothesis of strict crosssectional independence is rejected for all variables, except for the financial openness index.

\subsection{Panel quantile regression results}

In this section, we discuss the estimation results of the model specification involving the MMQR. To facilitate comparison, we first estimate the model by OLS regression. Results (taking into account robust standard errors) are shown in Table 8 considering pooled (columns 3 and 6), fixed (columns 1 and 4) and random effect (columns 2 and 5$)^{10}$. OLS results are also displayed in Figure 3 (see blue dotted lines). Overall, the signs and significance of the OLS-FE coefficients correspond to those observed in the MMQR. However, the OLS-FE describes only a partial picture of the empirical relationship between the variables, focusing on the mean effects.

\footnotetext{
${ }^{9}$ In line with existing literature, we note that the omission of financial openness from the carbon emissions model could result in possible biased and misleading empirical results. However, we also note that the research on financial openness and its effects on $\mathrm{CO}_{2}$ emissions is more recent and still in its infancy.

${ }^{10}$ Columns 4,5 and 6 refer to specifications involving regulatory quality directly in the regression. This specification is used as a robustness check, as discussed in Section 5.4.
} 


\begin{tabular}{|c|c|c|c|c|c|c|c|}
\hline Variable & time-lag & $\begin{array}{l}\text { Levels } \\
\text { inverse normal Z statistic }\end{array}$ & p-value for $Z$ statistic & number of observations & $\begin{array}{l}\text { 1st Differences } \\
\text { inverse normal Z statistic }\end{array}$ & p-value for $Z$ statistic & number of observations \\
\hline \multirow{2}{*}{$\mathrm{CO}_{2}$} & $\operatorname{lags}(1)$ & 2.629 & 0.996 & 342 & -8.497 & 0 & 342 \\
\hline & $\operatorname{lags}(3)$ & 0.918 & 0.821 & 342 & -2.378 & 0.00871 & 342 \\
\hline \multirow[t]{2}{*}{ Domcred } & $\operatorname{lags}(1)$ & -1.383 & 0.0833 & 312 & -6.103 & $5.20 \mathrm{e}-10$ & 306 \\
\hline & $\operatorname{lags}(3)$ & -0.541 & 0.294 & 312 & -1.871 & 0.0307 & 306 \\
\hline \multirow{2}{*}{$\mathrm{FFC}$} & $\operatorname{lags}(1)$ & 2.158 & 0.985 & 342 & -7.335 & 0 & 342 \\
\hline & $\operatorname{lags}(3)$ & 0.955 & 0.830 & 342 & -1.777 & 0.0378 & 342 \\
\hline \multirow[t]{2}{*}{ ChinnIto } & $\begin{array}{l}\operatorname{lags}(1) \\
\ln \end{array}$ & -0.154 & 0.439 & 342 & -4.379 & $5.96 \mathrm{e}-06$ & 342 \\
\hline & $\operatorname{lags}(3)$ & 1.476 & 0.930 & 342 & -0.506 & 0.306 & 342 \\
\hline \multirow{2}{*}{ GDP } & $\operatorname{lags}(1)$ & 0.835 & 0.798 & 342 & -7.619 & 0 & 342 \\
\hline & $\operatorname{lags}(3)$ & -0.154 & 0.439 & 342 & -2.483 & 0.00652 & 342 \\
\hline \multirow[t]{2}{*}{ Pop } & $\operatorname{lags}(1)$ & 1.528 & 0.937 & 342 & -4.665 & $1.54 \mathrm{e}-06$ & 342 \\
\hline & $\operatorname{lags}(3)$ & 0.713 & 0.762 & 342 & 0.246 & 0.597 & 342 \\
\hline \multirow{2}{*}{$\mathrm{ROA}$} & $\operatorname{lags}(1)$ & -5.075 & $1.94 \mathrm{e}-07$ & 342 & -11.61 & 0 & 342 \\
\hline & $\operatorname{lags}(3)$ & -3.523 & 0.000213 & 342 & -6.206 & $2.71 \mathrm{e}-10$ & 342 \\
\hline \multirow[t]{2}{*}{ STFP } & $\operatorname{lags}(1)$ & 2.942 & 0.998 & 342 & -8.370 & 0 & 323 \\
\hline & $\operatorname{lags}(3)$ & 2.979 & 0.999 & 342 & -7.505 & 0 & 323 \\
\hline \multirow[t]{2}{*}{ LTFP } & $\begin{array}{l}\operatorname{lags}(1) \\
\ln \end{array}$ & -1.050 & 0.147 & 342 & -2.967 & 0.00151 & 323 \\
\hline & $\operatorname{lags}(3)$ & -1.607 & 0.0541 & 342 & -2.896 & 0.00189 & 323 \\
\hline \multirow[t]{2}{*}{ TFP } & $\begin{array}{l}\operatorname{lags}(1) \\
\ln \end{array}$ & 3.896 & 1.000 & 342 & $\begin{array}{l}-5.434 \\
-\end{array}$ & $2.76 \mathrm{e}-08$ & 323 \\
\hline & $\operatorname{lags}(3)$ & 4.635 & 1.000 & 342 & -3.099 & 0.000969 & 323 \\
\hline
\end{tabular}

Table 5.: Dickey-Fuller test results

\begin{tabular}{llcc}
\hline \hline Test & & Test Statistic & p-value \\
\hline Pedroni & Modified Phillips-Perron & 2.8730 & 0.0020 \\
& Phillips-Perron & -7.6372 & 0.0000 \\
& Augmented Dickey-Fuller & -7.5883 & 0.0000 \\
\hline \multirow{2}{*}{ Kao } & Modified Dickey-Fuller & -0.2299 & 0.4091 \\
& Dickey-Fuller & -2.4571 & 0.0070 \\
& Augmented Dickey-Fuller & -2.2044 & 0.0137 \\
& Unadjusted modified Dickey-Fuller & 1.2270 & 0.1099 \\
& Unadjusted Dickey-Fuller & -1.5580 & 0.0596 \\
\hline Westerlund & Variance ratio & -1.3727 & 0.0849 \\
\hline \hline
\end{tabular}

Table 6.: Co-integration test results

\begin{tabular}{|c|c|c|c|c|c|}
\hline Variable & CD-test & p-value & "average joint $\mathrm{T}$ & mean $\rho$ & $\overline{\text { mean } \operatorname{abs}(\rho)}$ \\
\hline $\mathrm{CO}_{2}$ Emissions in metric tons in million & 4.439 & 0.000 & 18.00 & 0.08 & 0.74 \\
\hline GDP (in billion current US-Dollar) & 46.162 & 0.000 & 18.00 & 0.83 & 0.83 \\
\hline Squared GDP (in billion current US-Dollar) & 43.251 & 0.000 & 18.00 & 0.78 & 0.78 \\
\hline Population, in million & 32.83 & 0.000 & 18.00 & 0.59 & 0.81 \\
\hline Stock of long-term financial policies weighted by regulatory quality & 6.075 & 0.000 & 18.00 & 0.11 & 0.53 \\
\hline Stock of short-term financial policies weighted by regulatory quality & 2.718 & 0.007 & 18.00 & 0.05 & 0.43 \\
\hline Domestic credit to private sector (share of GDP) & 13.079 & 0.000 & 15.14 & 0.26 & 0.60 \\
\hline Chinn-Ito index & 0.081 & 0.936 & 18.00 & 0.00 & 0.07 \\
\hline Bank Return On Assets (Percentages, After Tax) & 7.368 & 0.000 & 18.00 & 0.13 & 0.29 \\
\hline Fossil fuel consumption in TWH per capita & 1.825 & 0.068 & 18.00 & 0.03 & 0.69 \\
\hline
\end{tabular}

Table 7.: Cross-sectional dependence 
By adopting the MMQR approach, the results provide a detailed description throughout the conditional distribution, especially in the countries with the most and least emissions. Moreover, we distinguish between the effects of the stock of recent (short-term) and older (long-term) climate-related financial policies. The MMQR estimation results are reported for the 10th, 20th, 30th, 40th, 50th, 60th, 70th, 80th, and 90th percentiles of the conditional $\mathrm{CO}_{2}$ emissions distribution. The lower quantiles include Argentina, Turkey, Australia, Brazil, France, Indonesia, Italy, South Africa. The higher quantiles refer to countries with higher $\mathrm{CO}_{2}$ emissions, such as Germany, Japan, the Russian Federation, India, the United States and China (See Figure 1 for more insights on the $\mathrm{CO}_{2}$ distribution).

The quantile regression results based on Equation 5 are shown in Table 9. Figure 3 shows the coefficients across all quantiles and the corresponding $95 \%$ confidence interval for all independent variables. Overall, the empirical results illustrate that the impact of the different variables included in the analysis is heterogeneous and indicate several important findings. First, they suggest that adopting a CRFP has an overall statistically significant negative effect on $\mathrm{CO}_{2}$ emissions, over both the short and the long term (see Table 9), thus implying that implementing climate-related financial policies improves the environmental quality in these countries. This result is a relevant contribution to the existing literature as it emphasizes the existence of a significant relationship between $\mathrm{CO}_{2}$ emissions and climate-related financial policies for the first time. The impact of long-term financial policies on $\mathrm{CO}_{2}$ emissions is significantly negative (at 1\% level) in all quantiles, while different effects are observed for short-term policies. For example, at the 10th quantile, the coefficient of STFP is negative but insignificant, indicating that these policies do not affect the environmental quality in countries with lower emissions. The rationale for this is that the majority of the countries which are located at the bottom of the $\mathrm{CO}_{2}$ distribution adopted the bulk of the CRFPs before 2015. Indeed, as discussed in Section 4.2, in countries like Australia, Brazil, France, and Indonesia, the adoption of CRFPs dates back to the early 2000s (see also the evidence reported in Figures 2 and A2). Additionally, we observe that for STFPs, their impact decreases in magnitude as we move from lower to higher quantiles of the distribution. The rationale for this is to be found in the type of policies adopted. In the short term (i.e., the period 2016-2017 in our analysis), the majority of the countries located at the top of the distribution have adopted only "soft" measures, such as "green finance principles" that are usually not binding for financial institutions, or disclosure requirements aimed at companies or non-financial institutions. Interestingly, when considering LTFPs, we note instead that their impact increases when moving from lower to higher emission countries. Also in this case the effect can be explained by combining the information on the total stock of policies and type. Specifically (1) the countries located at the top of the distribution adopted the bulk of the policies before 2015, and (2) they adopted mandatory prudential requirements and/or promotional credit measures, which contributed to improving environmental quality in these countries characterized by higher emissions.

Second, the effect of our indicator for financial development, i.e., domestic credit to the private sector, on $\mathrm{CO}_{2}$ emissions is negative across all quantiles at a $1 \%$ significance level. This result confirms that an increase in private credit contributes to improving environmental quality and is in line with a stream of the literature that points to a positive role played by financial development in decreasing environmental degradation. Indeed, as extensively discussed in Section 2, existing literature explains that financial development amplifies investments in modern technology that may reduce carbon emissions (see Shahbaz et al. 2016; Zaidi et al. 2019; Zafar et al. 2019, among oth- 
ers). Moreover, we argue that our findings on financial development are related to the overall climate-related financial landscape, i.e., green finance and policy developments characterizing G20s. As discussed in previous sections, our investigation of CRFPs reveals a major commitment to promoting sustainability and ecological investments in the past decades, which in turn "feeds-in" the overall financial development. Finally, we note the impact of financial development increases as we move towards the top of the distribution. This result is consistent with the evidence that more mature financial systems characterize these countries; this encourages green technology progress and hence alleviates $\mathrm{CO}_{2}$ emissions.

Third, regarding financial openness, negative signs characterize all quantiles, thus confirming the hypothesis that an improvement in financial infrastructure (based on the openness of capital account) may contribute to the efficient technological use and, therefore, affect the environmental degradation as well (Tamazian et al. 2009; Tamazian and Rao 2010; Jalil and Feridun 2011; You et al. 2015). However, heterogeneous effects are observed with respect to the coefficients for the 10th, 20th and 90th quantiles that are not significant. One the one hand this implies that the degree of financial openness of a country is associated with environmental degradation. On the other hand, this is not observed in countries with the highest and lowest emissions. Moreover, we note that significant coefficients are found in quantiles mainly refering to high- and upper-middle-income countries.

Fourth, regarding the indicator for financial soundness, i.e., bank return on assets, statistically significant results cannot be reported for all quantiles. Therefore, our analysis cannot support the hypothesis that a financially sound banking system is associated with environmental degradation (Kim et al. 2020).

Fifth, the estimated coefficients on GDP are positive and significant for all quantiles and all specifications. Moreover, the squared term - that is introduced to capture the non-linear effects of economic growth on carbon emissions - is negative, proving the EKC's existence, as discussed in Section 2. Regarding population, the estimated coefficients are positive and statistically significant for all quantiles - except the 10th quantile. The levels of significance vary across quantiles and are higher in the middle of the distribution. This result suggests that a larger population size could harm the environment's quality and aligns with existing empirical evidence provided by Sadorsky (2014); Yeh and Liao (2017); Dong et al. (2018).

Finally, regarding the effects of fossil fuel consumption, the estimated coefficients show a positive effect (at $5 \%$ and $1 \%$ level) on $\mathrm{CO}_{2}$ emissions. This confirms the evidence that $\mathrm{CO}_{2}$ emissions increase due to primary energy consumption (Acaravci and Ozturk 2010; Pao and Tsai 2011; Sheraz et al. 2021). Moreover, the observed impact is larger for lower quantiles and progressively decreases as we move towards higher quantiles. 

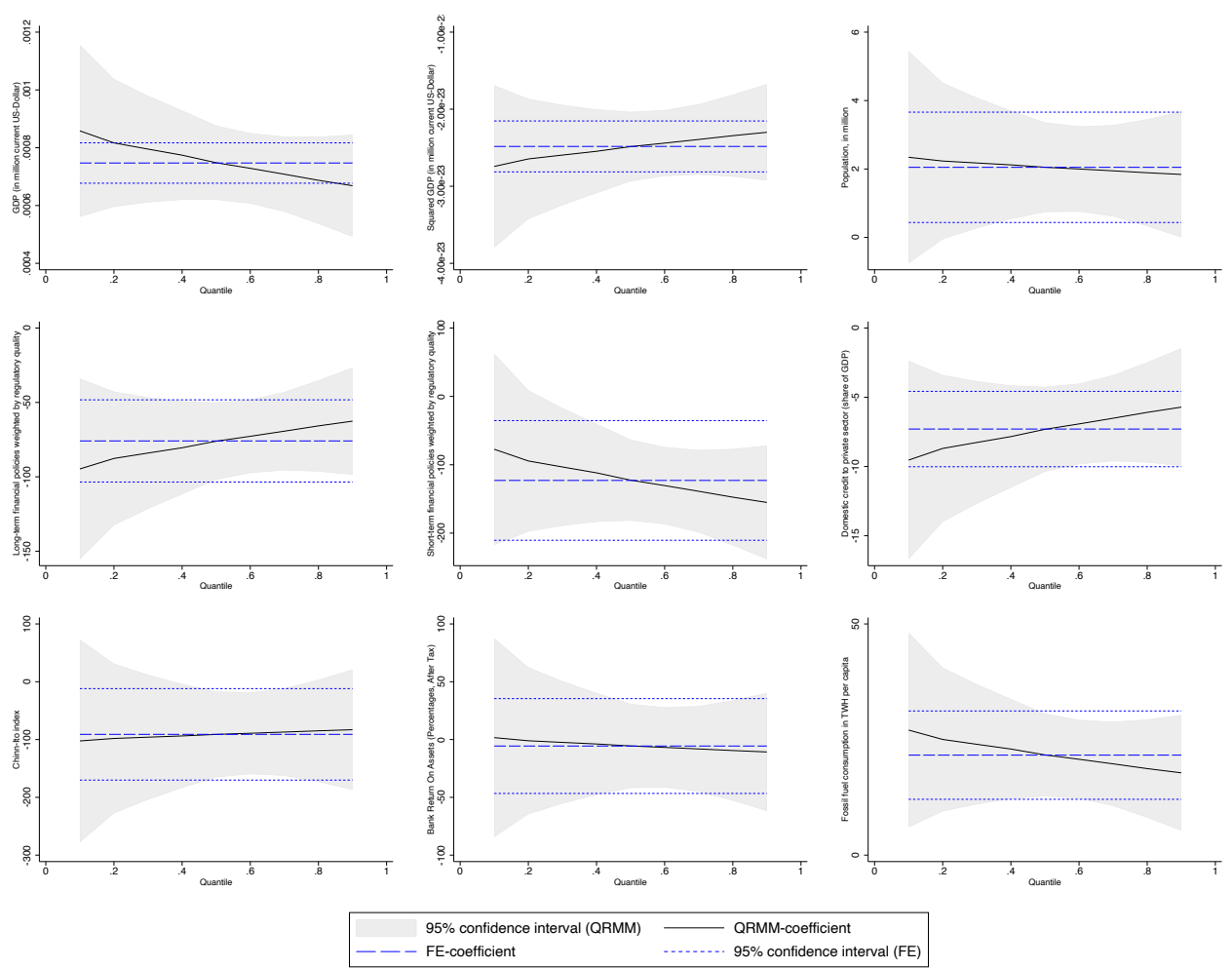

Figure 3.: Method of Moments Panel Quantile Regression results

\subsection{Direct, indirect and total effect}

Studying the direct and indirect influence mechanisms discussed in Section 5.3 allows us to prevent over- or under-estimating the real effects of climate-related financial policies on $\mathrm{CO}_{2}$ emissions. The regression results of the Equations 6 and 7 are reported in Table 10. They show statistically significant coefficients of GDP and GDP ${ }^{2}$, thus confirming the existence of EKC.

The results of this analysis are reported in Figure 4 and Tables 11 and 12, which demonstrate that both short-term and long-term financial policies directly affect emissions negatively at different levels of the distribution, implying an improvement of the environmental quality as discussed in Section 5.2. The magnitude of the LTFPs effect increases by moving from lower to higher quantiles, confirming the effects presented above. Regarding STFPs, results reported in Table 11 show that they have a larger direct impact on lower quantiles.

Considering the indirect effect, heterogeneity is observed among quantiles, as shown in Figure 4 (green lines). For LTFPs, negative coefficients are observed for higher quantiles, confirming their role in improving environmental quality in higher emission countries. Positive coefficients characterize instead lower quantiles, implying that these policies could worsen environmental quality in countries located at the bottom of the distribution. This evidence calls for increased attention to the type and the amount of climate-related financial policies implemented in these countries. For STFPs, the indirect effect is negative only in the 10th percentile and positive for all higher quantiles, implying an undesired worsening of these countries' environmental quality.

Overall, the total effect of policies is negative across all quantiles, for both short- 


\begin{tabular}{|c|c|c|c|c|c|c|}
\hline & $\begin{array}{l}(1) \\
\mathrm{FE}\end{array}$ & $\begin{array}{l}(2) \\
\mathrm{RE}\end{array}$ & $\begin{array}{c}(3) \\
\text { OLS }\end{array}$ & $\begin{array}{l}(4) \\
\mathrm{FE}\end{array}$ & $\begin{array}{l}(5) \\
\mathrm{RE}\end{array}$ & $\begin{array}{c}(6) \\
\text { OLS }\end{array}$ \\
\hline GDP (in billion current US-Dollar) & $\begin{array}{c}0.747^{* * * *} \\
(0.197)\end{array}$ & $\begin{array}{c}0.738^{* * *} \\
(0.181)\end{array}$ & $\begin{array}{l}0.775^{* * *} \\
(0.0672)\end{array}$ & $\begin{array}{c}0.771^{* * *} \\
(0.213)\end{array}$ & $\begin{array}{c}0.770^{* * *} \\
(0.198)\end{array}$ & $\begin{array}{l}0.781^{* * *} \\
(0.0648)\end{array}$ \\
\hline Squared GDP (in billion current US-Dollar) & $\begin{array}{c}-0.0000248^{* * *} \\
(0.00000708)\end{array}$ & $\begin{array}{c}-0.0000245^{* * *} \\
(0.00000677)\end{array}$ & $\begin{array}{c}-0.0000248^{* * *} \\
(0.00000351)\end{array}$ & $\begin{array}{c}-0.0000255^{* * *} \\
(0.00000760)\end{array}$ & $\begin{array}{c}-0.0000256^{* * *} \\
(0.00000729)\end{array}$ & $\begin{array}{c}-0.0000252^{* * *} \\
(0.00000342)\end{array}$ \\
\hline Population, in million & $\begin{array}{c}2.050 \\
(1.886)\end{array}$ & $\begin{array}{l}2.462^{* *} \\
(1.182)\end{array}$ & $\begin{array}{c}2.014^{* * *} \\
(0.239)\end{array}$ & $\begin{array}{c}2.446 \\
(1.948)\end{array}$ & $\begin{array}{l}2.695^{* *} \\
(1.136)\end{array}$ & $\begin{array}{c}1.996^{* * *} \\
(0.237)\end{array}$ \\
\hline Long-term financial policies weighted by regulatory quality & $\begin{array}{c}-75.83^{* * *} \\
(23.96)\end{array}$ & $\begin{array}{c}-75.33^{* * *} \\
(22.73)\end{array}$ & $\begin{array}{c}-53.95^{* * *} \\
(16.22)\end{array}$ & & & \\
\hline Short-term financial policies weighted by regulatory quality & $\begin{array}{c}-122.8^{* *} \\
(49.94)\end{array}$ & $\begin{array}{c}-121.0^{* * *} \\
(45.11)\end{array}$ & $\begin{array}{l}-70.63 \\
(47.55)\end{array}$ & & & \\
\hline Domestic credit to private sector (share of GDP) & $\begin{array}{c}-7.322^{*} \\
(4.088)\end{array}$ & $\begin{array}{l}-6.801^{*} \\
(3.809)\end{array}$ & $\begin{array}{l}-0.849 \\
(0.787)\end{array}$ & $\begin{array}{l}-6.621 \\
(3.937)\end{array}$ & $\begin{array}{c}-6.346^{*} \\
(3.762)\end{array}$ & $\begin{array}{c}-0.155 \\
(1.139)\end{array}$ \\
\hline Chinn-Ito index & $\begin{array}{c}-90.90 \\
(69.93)\end{array}$ & $\begin{array}{l}-104.5 \\
(71.19)\end{array}$ & $\begin{array}{c}-411.7^{* * * *} \\
(47.52)\end{array}$ & $\begin{array}{c}-121.4 \\
(72.62)\end{array}$ & $\begin{array}{l}-136.7^{*} \\
(72.65)\end{array}$ & $\begin{array}{c}-391.9^{* * *} \\
(53.37)\end{array}$ \\
\hline Bank Return On Assets (Percentages, After Tax) & $\begin{array}{c}-5.628 \\
(34.59)\end{array}$ & $\begin{array}{l}-4.187 \\
(34.74)\end{array}$ & $\begin{array}{c}46.31 \\
(36.80)\end{array}$ & $\begin{array}{l}-16.60 \\
(32.63)\end{array}$ & $\begin{array}{l}-13.39 \\
(32.46)\end{array}$ & $\begin{array}{c}47.88 \\
(34.32)\end{array}$ \\
\hline Fossil fuel consumption in TWH per capita & $\begin{array}{c}21.64 \\
(13.79)\end{array}$ & $\begin{array}{l}21.32^{*} \\
(11.27)\end{array}$ & $\begin{array}{c}20.65^{* * *} \\
(1.598)\end{array}$ & $\begin{array}{c}27.04 \\
(15.89)\end{array}$ & $\begin{array}{l}24.99^{* *} \\
(12.18)\end{array}$ & $\begin{array}{c}21.19^{* * * *} \\
(1.746)\end{array}$ \\
\hline Long-term financial policies & & & & $\begin{array}{c}-50.29^{* * *} \\
(13.77)\end{array}$ & $\begin{array}{c}-50.09^{* * *} \\
(12.81)\end{array}$ & $\begin{array}{l}-17.77 \\
(24.95)\end{array}$ \\
\hline Short-term financial policies & & & & $\begin{array}{l}-74.01 \\
(56.48)\end{array}$ & $\begin{array}{c}-75.67 \\
(54.78)\end{array}$ & $\begin{array}{c}72.42 \\
(73.23)\end{array}$ \\
\hline Regulatory Quality (Estimate) & & & & $\begin{array}{c}72.14 \\
(186.1)\end{array}$ & $\begin{array}{c}38.22 \\
(164.0)\end{array}$ & $\begin{array}{l}-157.5^{*} \\
(82.90)\end{array}$ \\
\hline Constant & $\begin{array}{c}-578.1 \\
(639.3) \\
\end{array}$ & $\begin{array}{l}-682.5 \\
(471.6) \\
\end{array}$ & $\begin{array}{c}-991.0^{* * * *} \\
(117.7) \\
\end{array}$ & $\begin{array}{c}-985.5 \\
(700.8) \\
\end{array}$ & $\begin{array}{l}-945.7^{*} \\
(491.6) \\
\end{array}$ & $\begin{array}{c}-1029.9^{* * *} \\
(122.4)\end{array}$ \\
\hline $\begin{array}{l}\text { Number of observations } \\
\text { R-squared }\end{array}$ & $\begin{array}{c}312 \\
0790\end{array}$ & $\begin{array}{c}312 \\
0790\end{array}$ & $\begin{array}{c}312 \\
0894\end{array}$ & $\begin{array}{c}312 \\
0781\end{array}$ & $\begin{array}{c}312 \\
0780\end{array}$ & $\begin{array}{c}312 \\
0894\end{array}$ \\
\hline $\begin{array}{l}\text { R-squared } \\
\text { P-value of F-statistics }\end{array}$ & $\begin{array}{c}0.790 \\
0.00627\end{array}$ & $\begin{array}{c}0.790 \\
0.0000142\end{array}$ & $\begin{array}{c}0.894 \\
1.62 \mathrm{e}-149\end{array}$ & $\begin{array}{c}0.781 \\
0.0000254\end{array}$ & $\begin{array}{c}0.780 \\
2.06 \mathrm{e}-22\end{array}$ & $\begin{array}{c}0.894 \\
1.67 \mathrm{e}-149\end{array}$ \\
\hline
\end{tabular}

Table 8.: Climate-related financial policies and their effects on $\mathrm{CO}_{2}$ emissions: OLS estimation results

\begin{tabular}{|c|c|c|c|c|c|c|c|c|c|}
\hline & $\begin{array}{c}1) \\
1 \\
1\end{array}$ & 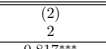 & $\begin{array}{c}(3) \\
3 \\
\end{array}$ & $\begin{array}{c}(4) \\
4 \\
4\end{array}$ & $\begin{array}{l}(5) \\
5 \\
\end{array}$ & $\begin{array}{c}(6) \\
6 \\
\end{array}$ & $\begin{array}{c}(7) \\
7 \\
\end{array}$ & $\begin{array}{c}(8) \\
8 \\
\end{array}$ & $\begin{array}{c}(9) \\
9 \\
\end{array}$ \\
\hline GDP (in billion current US-Dollar) & $\begin{array}{c}0.858^{*+* *+} \\
(0.152)\end{array}$ & $\begin{array}{c}0.817^{* * * *} \\
(0.112)\end{array}$ & $\begin{array}{l}0.795^{* * * *} \\
(0.0940)\end{array}$ & $\begin{array}{l}0.777^{* * * *} \\
(0.0786)\end{array}$ & $\begin{array}{l}0.749^{9^{* * *}} \\
(0.0655)\end{array}$ & $\begin{array}{l}0.729^{*+*} \\
(0.0621)\end{array}$ & $\begin{array}{l}0.709^{9 * *} \\
(0.0663)\end{array}$ & $\begin{array}{l}0.688^{* * * *} \\
(0.0768)\end{array}$ & $\begin{array}{l}0.669^{* * *} \\
(0.0898)\end{array}$ \\
\hline Squared GDP (in billion current US-Dollar) & $\begin{array}{c}-0.0000274^{* * *} \\
(0.00000537)\end{array}$ & $\begin{array}{l}-0.0000264^{* * *} \\
(0.00000397)\end{array}$ & $\begin{array}{c}-0.0000260^{* * *} \\
(0.00000332)\end{array}$ & $\begin{array}{l}-0.0000255^{* * *} \\
(0.00000276)\end{array}$ & $\begin{array}{l}-0.0000249^{* * *} \\
(0.00000230)\end{array}$ & $\begin{array}{c}-0.0000244^{* * *} \\
(0.00000218)\end{array}$ & $\begin{array}{l}-0.0000239^{* * *} \\
(0.00000233)\end{array}$ & $\begin{array}{l}-0.0000234^{* * *} \\
(0.00000271)\end{array}$ & $\begin{array}{c}-0.0000230^{* * *} \\
(0.00000318)\end{array}$ \\
\hline Population, in million & $\begin{array}{c}2.342 \\
(1.579)\end{array}$ & $\begin{array}{l}2.232^{*} \\
(1.164)\end{array}$ & $\begin{array}{l}2.176^{* *} \\
(0.972)\end{array}$ & $\begin{array}{l}2.121^{* * * *} \\
(0.807)\end{array}$ & (0.668) & $(0.635)$ & $\begin{array}{c}1.948^{8 * *} \\
(0.680)\end{array}$ & $\begin{array}{l}1.893^{* * *} \\
(0.796)\end{array}$ & $\begin{array}{l}1.844^{* * *} \\
(0.937)\end{array}$ \\
\hline Long-term financial policies weighted by regulatory quality & $\begin{array}{c}-94.76^{* * *} \\
(30.94)\end{array}$ & $\begin{array}{c}-87.66^{* * *} \\
(22.88)\end{array}$ & $\begin{array}{c}-84.02^{* * * *} \\
(19.11)\end{array}$ & $\begin{array}{c}-80.42^{* * *} \\
(15.92)\end{array}$ & $\begin{array}{c}-76.03^{* * *} \\
(13.23)\end{array}$ & $\begin{array}{c}-72.69^{* * *} \\
(12.56)\end{array}$ & $\begin{array}{c}-69.22^{* * *} \\
(13.43)\end{array}$ & $\begin{array}{c}-65.66^{* * *} \\
(15.62)\end{array}$ & $\begin{array}{c}-62.49^{* * * *} \\
(18.35)\end{array}$ \\
\hline Short-term financial policies weighted by regulatory quality & $\begin{array}{l}-77.81 \\
(71.49)\end{array}$ & $\begin{array}{l}-94.67^{*} \\
(52.73)\end{array}$ & $\begin{array}{l}-103.3^{* * *} \\
(44.00)\end{array}$ & $\begin{array}{c}-111.8^{* * *} \\
(36.57)\end{array}$ & $\begin{array}{c}-122.3^{* * *} \\
(30.31)\end{array}$ & $\begin{array}{l}-130.2^{* * *} \\
(28.80)\end{array}$ & $\begin{array}{c}-138.4^{* * *} \\
(30.83)\end{array}$ & $\begin{array}{l}-146.9^{* * * *} \\
(36.01)\end{array}$ & $\begin{array}{c}-154.4^{* * *} \\
(42.41)\end{array}$ \\
\hline Domestic credit to private sector (share of GDP) & $\begin{array}{c}-9.542^{* * *} \\
(3.652)\end{array}$ & $\begin{array}{c}-8.709^{* * *} \\
(2.701)\end{array}$ & $\begin{array}{c}-8.283^{* * *} \\
(2.256)\end{array}$ & $\begin{array}{c}-7.861^{* * *} \\
(1.879)\end{array}$ & $\begin{array}{c}-7.346^{* * *} \\
(1.562)\end{array}$ & $\begin{array}{c}-6.954^{* * *} \\
(1.483)\end{array}$ & $\begin{array}{c}-6.548^{* * *} \\
(1.585)\end{array}$ & $\begin{array}{c}-6.130^{* * *} \\
(1.844)\end{array}$ & $\begin{array}{c}-5.759^{* * *} \\
(2.165)\end{array}$ \\
\hline Chinn-Ito index & $\begin{array}{l}-102.3 \\
(89.33)\end{array}$ & $\begin{array}{l}-98.02 \\
(65.91)\end{array}$ & $\begin{array}{l}-95.83^{*} \\
(55.02)\end{array}$ & $\begin{array}{l}-93.67^{* *} \\
(45.71)\end{array}$ & $\begin{array}{l}-91.02^{* *} \\
(37.87)\end{array}$ & $\begin{array}{l}-89.01^{* *} \\
(36.02)\end{array}$ & $\begin{array}{l}-86.92^{* *} \\
(38.54)\end{array}$ & $\begin{array}{l}-84.77^{*} \\
(45.03)\end{array}$ & $\begin{array}{l}-82.86 \\
(52.99)\end{array}$ \\
\hline Bank Return On Assets (Percentages, After Tax) & $\begin{array}{r}1.713 \\
(43.85)\end{array}$ & $\begin{array}{l}-1.041 \\
(32.34)\end{array}$ & $\begin{array}{l}-2.451 \\
(27.00)\end{array}$ & $\begin{array}{l}-3.845 \\
(22.43)\end{array}$ & $\begin{array}{l}-5.549 \\
(18.58)\end{array}$ & $\begin{array}{l}-6.845 \\
(17.67)\end{array}$ & $\begin{array}{l}-8.189 \\
(18.91)\end{array}$ & $\begin{array}{l}-9.569 \\
(22.10)\end{array}$ & $\begin{array}{l}-10.80 \\
(26.01)\end{array}$ \\
\hline Fossil fuel consumption in TWH per capita & $\begin{array}{l}27.04^{* * *} \\
(10.72)\end{array}$ & $\begin{array}{c}25.011^{* * *} \\
(7.919)\end{array}$ & $\begin{array}{r}23.97^{* * * *} \\
(6.612)\end{array}$ & $\begin{array}{c}22.95^{5 * * *} \\
(5.500)\end{array}$ & $\begin{array}{l}21.77^{* * * * *} \\
(4.563)\end{array}$ & $\begin{array}{c}20.74^{* * * *} \\
(4.336)\end{array}$ & $\begin{array}{c}19.75^{5 * * *} \\
(4.638)\end{array}$ & $\begin{array}{c}\begin{array}{c}18.74^{4 * * *} \\
(5.408)\end{array} \\
\end{array}$ & $\begin{array}{l}17.88^{4 * * *} \\
(6.360)\end{array}$ \\
\hline $\bar{N}$ & 312 & 312 & 312 & 312 & 312 & 312 & 312 & 312 & 312 \\
\hline
\end{tabular}

Table 9.: Climate-related financial policies and their effects on $\mathrm{CO}_{2}$ emissions: panel quantile regression results. 
and long-term policies, as shown in Figure 4 (blue lines), confirming that these policies have an impact on environmental quality.

\begin{tabular}{|c|c|c|}
\hline Dependent variable: & $\begin{array}{c}(1) \\
\mathrm{CO}_{2} \text { emissions }\end{array}$ & $\begin{array}{c}(2) \\
\text { GDP }\end{array}$ \\
\hline GDP (in billion current US-Dollar) & $\begin{array}{l}0.747^{* * *} \\
(0.0356)\end{array}$ & \\
\hline Squared GDP (in billion current US-Dollar) & $\begin{array}{c}-0.0000248^{* * * *} \\
(0.00000169)\end{array}$ & \\
\hline Domestic credit to private sector (share of GDP) & $\begin{array}{c}-7.322^{* * * *} \\
(1.390)\end{array}$ & \\
\hline Chinn-Ito index & $\begin{array}{c}-90.90^{* *} \\
(40.37)\end{array}$ & \\
\hline Bank Return On Assets (Percentages, After Tax) & $\begin{array}{l}-5.628 \\
(20.92)\end{array}$ & \\
\hline Fossil fuel consumption in TWH per capita & $\begin{array}{c}21.64^{* * *} \\
(4.872)\end{array}$ & \\
\hline Population, in million & $\begin{array}{l}2.050^{* *} \\
(0.822)\end{array}$ & $\begin{array}{c}0.597 \\
(0.608)\end{array}$ \\
\hline Long-term financial policies weighted by regulatory quality & $\begin{array}{c}-75.83^{* * *} \\
(14.09)\end{array}$ & $\begin{array}{l}-18.73^{*} \\
(9.758)\end{array}$ \\
\hline Short-term financial policies weighted by regulatory quality & $\begin{array}{c}-122.8^{* * * *} \\
(44.64)\end{array}$ & $\begin{array}{l}-30.94 \\
(30.47)\end{array}$ \\
\hline Inflation & & $\begin{array}{l}1.505 \\
(2.794)\end{array}$ \\
\hline Gross capital formation (percent of GDP) & & $\begin{array}{c}15.31^{* * * *} \\
(4.659)\end{array}$ \\
\hline GDP (in billion current US-Dollar)( $\mathrm{t}-1$ ) & & $\begin{array}{l}1.009^{* * * *} \\
(0.0119)\end{array}$ \\
\hline Constant & $\begin{array}{c}-578.1^{* *} \\
(242.7) \\
\end{array}$ & $\begin{array}{c}-418.1^{* * *} \\
(151.5) \\
\end{array}$ \\
\hline $\mathrm{N}$ & 312 & 324 \\
\hline R-squared & 0.790 & 0.971 \\
\hline
\end{tabular}

Table 10.: The regression results of the $\mathrm{CO}_{2}$ and GDP equations (Eqs. 6 and 7, respectively)
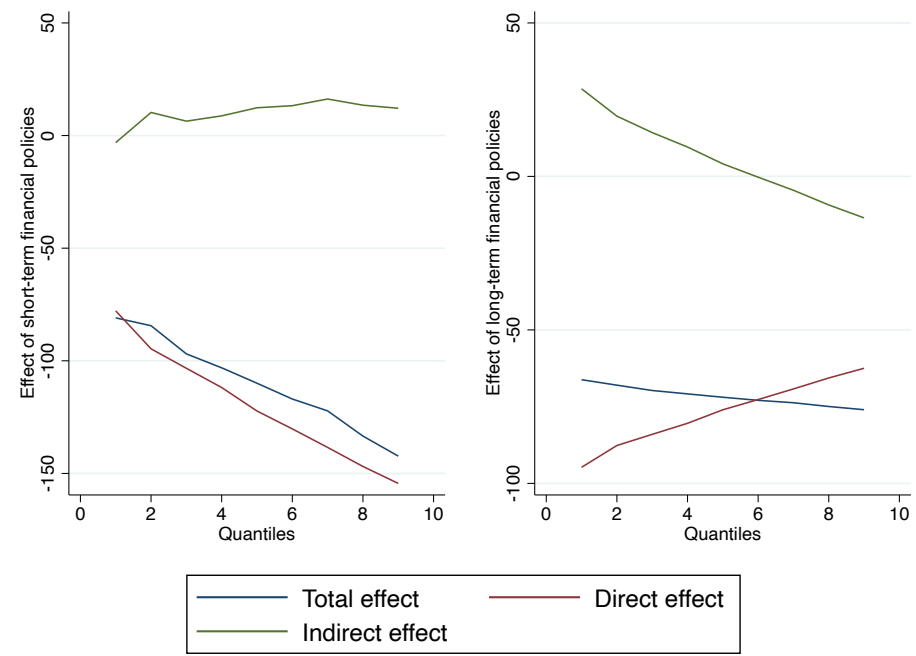

Figure 4.: The direct, indirect and total effect of short term (left plot) and long term (right plot) CRFPs on the $\mathrm{CO}_{2}$ distribution 


\begin{tabular}{cccc}
\hline Quantile & Total effect & Direct effect & Indirect effect \\
\hline 1 & -80.92704 & -77.81095 & -3.116089 \\
2 & -84.41449 & -94.67371 & 10.25922 \\
3 & -96.91357 & -103.3075 & 6.393929 \\
4 & -103.0959 & -111.8441 & 8.748146 \\
5 & -109.9328 & -122.2746 & 12.34183 \\
6 & -116.9494 & -130.2092 & 13.25974 \\
7 & -122.218 & -138.4381 & 16.22008 \\
8 & -133.3991 & -146.8899 & 13.4908 \\
9 & -142.285 & -154.4163 & 12.13132 \\
\hline
\end{tabular}

Table 11.: Direct, indirect and total effect of short-term policies

\begin{tabular}{cccc}
\hline Quantile & Total effect & Direct effect & Indirect effect \\
\hline 1 & -66.21326 & -94.76025 & 28.54699 \\
2 & -68.00264 & -87.6566 & 19.65396 \\
3 & -69.73299 & -84.01952 & 14.28652 \\
4 & -70.8371 & -80.42339 & 9.586281 \\
5 & -71.92606 & -76.02938 & 4.103325 \\
6 & -72.93642 & -72.68686 & -.2495651 \\
7 & -73.72478 & -69.22034 & -4.504448 \\
8 & -74.95133 & -65.65988 & -9.291451 \\
9 & -75.99686 & -62.48929 & -13.50758 \\
\hline
\end{tabular}

Table 12.: Direct, indirect and total effect of long-term policies

\subsection{Alternative model specifications}

To gain further insights into our research question, we run three additional specifications of the model. Specification I does not consider regulatory quality in implementing long-run and short-run policies; rather, regulatory quality enters the regression directly as an explanatory variable. These results are shown in Table 13. Specifications II and III exclude the recent and older stock of policies and consider the cumulated stock instead, i.e., the total stock of policies over 2000-2017, without any distinction between the long- and short-term. Moreover, the specifications distinguish the consideration (Specification II) or exclusion (Specification III) of the implementation's regulatory quality. Results are are reported in Tables 15 and 14 respectively.

Overall, the results from these various alternative specifications largely support the findings discussed in Section 5.2. The effect of LTFP, STFP and cumulated policies are negative and heterogeneous across different quantiles in the conditional distribution of $\mathrm{CO}_{2}$ emissions. However, in Specifications I and III (excluding the implementation's regulatory quality in the interaction term), significant effects are observed only for higher quantiles, namely the 60th, 70th and 80th for LTFP and 60th, 70th, 80th, 90th for STFP. Regarding the effects of the cumulated policies, they are also found to improve environmental quality across all quantiles. In Specification II, the coefficients are not significant for countries located at the bottom of the distribution, i.e., those with lower emissions. This is consistent with the result discussed in Section 5.2. Our finding shows that domestic credit to the private sector is statistically significant at almost all quantiles across all specifications and has a negative impact on $\mathrm{CO}_{2}$ emissions. Coefficients for other control variables are similar to the results reported above and do not seem to be sensitive to a particular estimation procedure or alternative measures 
of climate-related policies. Thus, we conclude that the results reported in this paper are robust.

\begin{tabular}{|c|c|c|c|c|c|c|c|c|c|}
\hline GDP (in billion current US-Dollar) & $\begin{array}{c}(1) \\
1 \\
0.854^{* * * *} \\
(0.302)\end{array}$ & $\begin{array}{c}\frac{(2)}{2} \\
0.827^{* * * *} \\
(0.238)\end{array}$ & $\begin{array}{c}(3) \\
3 \\
0.806^{* * * *} \\
(0.190)\end{array}$ & $\begin{array}{c}(4) \\
4 \\
40.788^{* * * *} \\
(0.149)\end{array}$ & $\begin{array}{c}(5) \\
5 \\
0.774^{* * * *} \\
(0.121)\end{array}$ & $\begin{array}{c}(6) \\
6 \\
0.755^{* * * *} \\
(0.0910)\end{array}$ & $\begin{array}{c}(7) \\
7 \\
0.741^{* * *} \\
(0.0809)\end{array}$ & $\begin{array}{c}(8) \\
8 \\
0.724^{* * * *} \\
(0.0877)\end{array}$ & $\begin{array}{c}(9) \\
9 \\
0.710^{* * * *} \\
(0.107)\end{array}$ \\
\hline Squared GDP (in billion current US-Dollar) & $\begin{array}{c}-0.0000270^{* *} \\
(0.0000107)\end{array}$ & $\begin{array}{c}-0.00002655^{* * *} \\
(0.00000845)\end{array}$ & $\begin{array}{c}-0.0000261^{* * *} \\
(0.0000675)\end{array}$ & $\begin{array}{c}-0.0000258^{* * *} \\
(0.00000528)\end{array}$ & $\begin{array}{c}-0.0000255^{* * * *} \\
(0.00000430)\end{array}$ & $\begin{array}{c}-0.0000252^{* * *} \\
(0.00000323)\end{array}$ & $\begin{array}{c}-0.0000249^{* * *} \\
(0.00000287)\end{array}$ & $\begin{array}{c}-0.0000246^{* * *} \\
(0.0000311)\end{array}$ & $\begin{array}{c}-0.0000243^{* * *} \\
(0.00000381)\end{array}$ \\
\hline Population, in million & $\begin{array}{l}2.879 \\
(2.947)\end{array}$ & $\begin{array}{c}2.738 \\
(2.320)\end{array}$ & $\begin{array}{c}2.630 \\
(1.853)\end{array}$ & $\begin{array}{l}2.532^{*} \\
(1.449)\end{array}$ & $\begin{array}{l}2.460^{* * *} \\
(1.178)\end{array}$ & $\begin{array}{l}2.359^{* * *} \\
(0.883)\end{array}$ & $\begin{array}{l}2.286^{* * * *} \\
(0.784)\end{array}$ & $\begin{array}{l}2.198^{* * * *} \\
(0.852)\end{array}$ & $\begin{array}{l}2.123^{* *} \\
(1.044)\end{array}$ \\
\hline Long-term financial policies & $\begin{array}{l}-61.45 \\
(62.74)\end{array}$ & $\begin{array}{l}-57.83 \\
(49.39)\end{array}$ & $\begin{array}{l}-55.05 \\
(39.45)\end{array}$ & $\begin{array}{l}-52.52^{*} \\
(30.86)\end{array}$ & $\begin{array}{c}-50.65^{* *} \\
(25.10)\end{array}$ & $\begin{array}{l}-48.06^{* *} \\
(18.84)\end{array}$ & $\begin{array}{c}-46.18^{* * * *} \\
(16.74)\end{array}$ & $\begin{array}{l}-43.92^{* *} \\
(18.17)\end{array}$ & $\begin{array}{l}-41.98^{*} \\
(22.25)\end{array}$ \\
\hline Short-term financial policies & $\begin{array}{l}-27.82 \\
(143.0)\end{array}$ & $\begin{array}{l}-42.80 \\
(112.6)\end{array}$ & $\begin{array}{l}-54.31 \\
(89.90)\end{array}$ & $\begin{array}{l}-64.79 \\
(70.33)\end{array}$ & $\begin{array}{l}-72.51 \\
(57.19)\end{array}$ & $\begin{array}{l}-83.21^{*} \\
(42.92)\end{array}$ & $\begin{array}{c}-91.00^{* *} \\
(38.12)\end{array}$ & $\begin{array}{l}-100.4^{* *} \\
(41.38)\end{array}$ & $\begin{array}{c}-108.4^{* *} \\
(50.70)\end{array}$ \\
\hline Regulatory Quality (Estimate) & $\begin{array}{l}296.7 \\
(524.9)\end{array}$ & $\begin{array}{l}223.9 \\
(413.3)\end{array}$ & $\begin{array}{c}167.9 \\
(330.1)\end{array}$ & $\begin{array}{c}117.0 \\
(258.4)\end{array}$ & $\begin{array}{c}79.46 \\
(210.2)\end{array}$ & $\begin{array}{l}27.44 \\
(158.1)\end{array}$ & $\begin{array}{l}-10.42 \\
(140.4)\end{array}$ & $\begin{array}{l}-55.91 \\
(152.2)\end{array}$ & $\begin{array}{l}-94.96 \\
(186.3)\end{array}$ \\
\hline Domestic credit to private sector (share of GDP) & $\begin{array}{l}-7.128 \\
(6.871)\end{array}$ & $\begin{array}{l}-6.964 \\
(5.409)\end{array}$ & $\begin{array}{l}-6.837 \\
(4.319)\end{array}$ & $\begin{array}{c}-6.723^{* *} \\
(3.379)\end{array}$ & $\begin{array}{c}-6.638^{* *} \\
(2.747)\end{array}$ & $\begin{array}{c}-6.521^{* * * *} \\
(2.062)\end{array}$ & $\begin{array}{c}-6.435^{* * *} \\
(1.832)\end{array}$ & $\begin{array}{c}-6.333^{* * * *} \\
(1.989)\end{array}$ & $\begin{array}{l}-6.244^{* * *} \\
(2.436)\end{array}$ \\
\hline Chinn-Ito index & $\begin{array}{l}-155.8 \\
(173.9)\end{array}$ & $\begin{array}{l}-144.7 \\
(137.0)\end{array}$ & $\begin{array}{l}-136.1 \\
(109.4)\end{array}$ & $\begin{array}{l}-128.3 \\
(85.56)\end{array}$ & $\begin{array}{l}-122.6^{*} \\
(69.59)\end{array}$ & $\begin{array}{l}-114.6^{* *} \\
(52.25)\end{array}$ & $\begin{array}{c}-108.8^{* *} \\
(46.43)\end{array}$ & $\begin{array}{l}-101.8^{* *} \\
(50.40)\end{array}$ & $\begin{array}{l}-95.84 \\
(61.70)\end{array}$ \\
\hline Bank Return On Assets (Percentages, After Tax) & $\begin{array}{l}-11.66 \\
(85.94)\end{array}$ & $\begin{array}{l}-13.26 \\
(67.66)\end{array}$ & $\begin{array}{l}-14.49 \\
(54.02)\end{array}$ & $\begin{array}{l}-15.61 \\
(42.25)\end{array}$ & $\begin{array}{l}-16.44 \\
(34.35)\end{array}$ & $\begin{array}{l}-17.59 \\
(25.77)\end{array}$ & $\begin{array}{l}-18.42 \\
(22.89)\end{array}$ & $\begin{array}{l}-19.42 \\
(24.87)\end{array}$ & $\begin{array}{l}-20.28 \\
(30.46)\end{array}$ \\
\hline Fossil fuel consumption in TWH per capita & $\begin{array}{l}30.57 \\
(22.19)\end{array}$ & $\begin{array}{l}29.43^{*} \\
(17.47) \\
312\end{array}$ & $\begin{array}{l}28.55^{* *} \\
(13.95) \\
312\end{array}$ & $\begin{array}{l}27.75^{* *} \\
(10.91)\end{array}$ & $\begin{array}{c}27.16^{* * *} \\
(8.876)\end{array}$ & $\begin{array}{c}26.34^{* * *} \\
(6.662) \\
312\end{array}$ & $\begin{array}{c}25.74^{* * * *} \\
(5.919) \\
312\end{array}$ & $\begin{array}{c}25.03^{* * *} \\
(6.426) \\
\end{array}$ & $\begin{array}{c}24.41^{* * * *} \\
(7.869) \\
.210\end{array}$ \\
\hline $\mathrm{N}$ & 312 & 312 & 312 & 312 & 312 & 312 & 312 & 312 & 312 \\
\hline
\end{tabular}

Table 13.: Robustness analysis: long-term stock \& short-term stock of policies

\begin{tabular}{|c|c|c|c|c|c|c|c|c|c|}
\hline GDP (in billion current US-Dollar) & 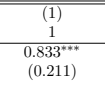 & $\begin{array}{c}(2) \\
2 \\
0.815^{* * * *} \\
(0.163)\end{array}$ & $\begin{array}{c}(3) \\
3 \\
0.803^{* * * *} \\
(0.132)\end{array}$ & 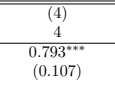 & $\begin{array}{c}(5) \\
5 \\
0.780^{* * * *} \\
(0.0829)\end{array}$ & $\begin{array}{c}(6) \\
6 \\
0.770^{* * * * *} \\
(0.0719)\end{array}$ & $\begin{array}{c}(7) \\
7 \\
0.760^{* * * *} \\
(0.0718)\end{array}$ & $\begin{array}{c}(8) \\
8 \\
0.752^{* * * *} \\
(0.0796)\end{array}$ & $\begin{array}{c}(9) \\
9 \\
0.742^{* * *} \\
(0.0974)\end{array}$ \\
\hline Squared GDP (in billion current US-Dollar) & $\begin{array}{c}-0.0000259^{* * *} \\
(0.00000745)\end{array}$ & $\begin{array}{c}-0.0000257^{* * *} \\
(0.00000574)\end{array}$ & $\begin{array}{c}-0.0000256^{* * *} \\
(0.00000466)\end{array}$ & $\begin{array}{c}-0.0000255^{* * *} \\
(0.00000378)\end{array}$ & $\begin{array}{c}-0.0000254^{* * *} \\
(0.00000292)\end{array}$ & $\begin{array}{c}-0.0000254^{* * * *} \\
(0.00000253)\end{array}$ & $\begin{array}{c}-0.0000253^{* * *} \\
(0.00000253)\end{array}$ & $\begin{array}{c}-0.0000252^{* * *} \\
(0.00000281)\end{array}$ & $\begin{array}{c}-0.0000251^{* * *+} \\
(0.00000344)\end{array}$ \\
\hline Population, in million & $\begin{array}{l}3.828^{*} \\
(2.243)\end{array}$ & $\begin{array}{l}3.457^{* *} \\
(1.730)\end{array}$ & $\begin{array}{l}3.208^{* *} \\
(1.403)\end{array}$ & $\begin{array}{l}2.989^{* * *} \\
(1.140)\end{array}$ & $\begin{array}{l}2.724^{* * *} \\
(0.880)\end{array}$ & $\begin{array}{l}2.521^{* * * *} \\
(0.763)\end{array}$ & $\begin{array}{l}2.301^{* * *} \\
(0.761)\end{array}$ & $\begin{array}{l}2.140^{* *} \\
(0.847)\end{array}$ & $\begin{array}{l}1.928^{*} \\
(1.037)\end{array}$ \\
\hline Cumulated total financial policies & $\begin{array}{l}-50.04 \\
(38.62)\end{array}$ & $\begin{array}{l}-49.58^{*} \\
(29.79)\end{array}$ & $\begin{array}{l}-49.26^{* *} \\
(24.17)\end{array}$ & $\begin{array}{c}-48.99^{* *} \\
(19.61)\end{array}$ & $\begin{array}{c}-48.66^{* * * *} \\
(15.13)\end{array}$ & $\begin{array}{c}-48.411^{* * *} \\
(13.11)\end{array}$ & $\begin{array}{c}-48.13^{* * *} \\
(13.11)\end{array}$ & $\begin{array}{c}-47.93^{* * * *} \\
(14.58)\end{array}$ & $\begin{array}{c}-47.66^{* * * *} \\
(17.85)\end{array}$ \\
\hline Regulatory Quality (Estimate) & $\begin{array}{c}341.2 \\
(362.4)\end{array}$ & $\begin{array}{c}260.5 \\
(279.9)\end{array}$ & $\begin{array}{l}206.3 \\
(227.0)\end{array}$ & $\begin{array}{c}158.6 \\
(184.8)\end{array}$ & $\begin{array}{c}101.0 \\
(143.3)\end{array}$ & $\begin{array}{c}56.75 \\
(124.2)\end{array}$ & $\begin{array}{c}9.055 \\
(123.7)\end{array}$ & $\begin{array}{l}-26.13 \\
(137.0)\end{array}$ & $\begin{array}{l}-72.27 \\
(167.9)\end{array}$ \\
\hline Domestic credit to private sector (share of GDP) & $\begin{array}{l}-6.429 \\
(4.656)\end{array}$ & $\begin{array}{l}-6.183^{*} \\
(3.592)\end{array}$ & $\begin{array}{l}-6.018^{* *} \\
(2.914)\end{array}$ & $\begin{array}{l}-5.872^{* *} \\
(2.366)\end{array}$ & $\begin{array}{c}-5.697^{* * * *} \\
(1.826)\end{array}$ & $\begin{array}{c}-5.562^{* * * *} \\
(1.583)\end{array}$ & $\begin{array}{c}-5.416^{* * * *} \\
(1.582)\end{array}$ & $\begin{array}{c}-5.309^{* * * *} \\
(1.759)\end{array}$ & $\begin{array}{r}-5.168^{* *} \\
(2.152)\end{array}$ \\
\hline Chinn-Ito index & $\begin{array}{l}-199.5^{*} \\
(118.3)\end{array}$ & $\begin{array}{l}-176.5^{*} \\
(91.38)\end{array}$ & $\begin{array}{c}-161.1^{* * *} \\
(74.12)\end{array}$ & $\begin{array}{l}-147.5^{* *} \\
(60.33)\end{array}$ & $\begin{array}{c}-131.2^{* * * *} \\
(46.77)\end{array}$ & $\begin{array}{c}-118.6^{* * * *} \\
(40.56)\end{array}$ & $\begin{array}{c}-105.0^{* * * *} \\
(40.40)\end{array}$ & $\begin{array}{l}-94.97^{* *} \\
(44.75)\end{array}$ & $\begin{array}{l}-81.84 \\
(54.80)\end{array}$ \\
\hline Bank Return On Assets (Percentages, After Tax) & $\begin{array}{l}-16.16 \\
(57.18)\end{array}$ & $\begin{array}{l}-16.67 \\
(44.10)\end{array}$ & $\begin{array}{l}-17.01 \\
(35.78)\end{array}$ & $\begin{array}{l}-17.31 \\
(29.03)\end{array}$ & $\begin{array}{l}-17.68 \\
(22.39)\end{array}$ & $\begin{array}{l}-17.96 \\
(19.41)\end{array}$ & $\begin{array}{l}-18.26 \\
(19.41)\end{array}$ & $\begin{array}{l}-18.48 \\
(21.59)\end{array}$ & $\begin{array}{l}-18.77 \\
(26.42)\end{array}$ \\
\hline Fossil fuel consumption in TWH per capita & $\begin{array}{l}\begin{array}{l}31.14^{* * *} \\
(15.26)\end{array} \\
12\end{array}$ & $\begin{array}{l}\begin{array}{l}29.17^{* * *} \\
(11.78)\end{array} \\
32\end{array}$ & $\begin{array}{r}27.84^{* * *} \\
(9.553) \\
\end{array}$ & $\begin{array}{c}26.68^{* * * *} \\
(7.763) \\
\end{array}$ & $\begin{array}{c}25.27^{* * * *} \\
(6.003) \\
\end{array}$ & $\begin{array}{c}24.19^{* * * *} \\
(5.205) \\
\end{array}$ & $\begin{array}{r}23.03^{* * * *} \\
(5.195) \\
\end{array}$ & $\begin{array}{c}22.17^{* * *} \\
(5.766) \\
\end{array}$ & $\begin{array}{c}21.05^{* * *} \\
(7.058)\end{array}$ \\
\hline $\bar{N}$ & 312 & 312 & 312 & 312 & 312 & 312 & 312 & 312 & 312 \\
\hline
\end{tabular}

Table 14.: Robustness analysis: cumulated stock of policies

\section{Conclusions and policy implications}

This paper aims to study the effects of financial and economic development, energy consumption, and climate-related financial policies on $\mathrm{CO}_{2}$ emissions in G20 countries. This analysis is relevant because the devastating consequences of environmental degradation on humanity and economic systems represent a pressing issue for governments and societies. Indeed, according to the latest IPCC (2018) report, G20 countries need to cut their current emissions by at least $45 \%$ in 2030 (below 2010 levels) to be in line with global benchmarks set on $1.5^{\circ} \mathrm{C}$. Against this backdrop, in the past two decades, G20 countries have implemented a wide range of policy instruments, including different climate-related financial policies, to affect climate change and achieve effective mitigation results. 


\begin{tabular}{|c|c|c|c|c|c|c|c|c|c|}
\hline & 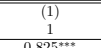 & $\begin{array}{l}\frac{(2)}{2} \\
2 \\
\end{array}$ & 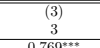 & 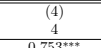 & $\begin{array}{l}(5) \\
5 \\
\end{array}$ & $\begin{array}{c}(6) \\
6 \\
\\
\end{array}$ & $\begin{array}{c}(7) \\
7 \\
79^{* x *}\end{array}$ & 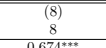 & 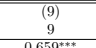 \\
\hline GDP (in billion current US-Dollar) & $\begin{array}{l}0.825^{2 * * *} \\
(0.151)\end{array}$ & $\begin{array}{c}\begin{array}{c}0.794^{* * *} \\
(0.118)\end{array} \\
\end{array}$ & $\begin{array}{l}.769^{2 * n+1} \\
(0.0935)\end{array}$ & $\begin{array}{l}0.753^{* * *+1} \\
(0.0799)\end{array}$ & $\begin{array}{l}0.731^{1 * * *} \\
(0.0669)\end{array}$ & $\begin{array}{l}0.713^{* * * *} \\
(0.0629)\end{array}$ & $\begin{array}{l}0.692^{2 * * *} \\
(0.0672)\end{array}$ & $\begin{array}{l}0.677^{4 * * *} \\
(0.0773)\end{array}$ & 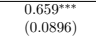 \\
\hline Squared GDP (in billion current US-Dollar) & $\begin{array}{c}-0.0000259^{* * *} \\
(0.00000548)\end{array}$ & $\begin{array}{c}-0.0000252^{* * *} \\
(0.00000426)\end{array}$ & $\begin{array}{c}-0.0000247^{* * *} \\
(0.00000337)\end{array}$ & $\begin{array}{c}-0.0000244^{* * *} \\
(0.00000288)\end{array}$ & $\begin{array}{c}-0.0000239^{* * *} \\
(0.00000239)\end{array}$ & $\begin{array}{c}-0.0000233^{* * *} \\
(0.0000225)\end{array}$ & $\begin{array}{c}-0.0000232 * * * \\
(0.00000241)\end{array}$ & $\begin{array}{l}-0.0000222^{* * *} \\
(0.00000279)\end{array}$ & $\begin{array}{c}-0.0000225^{* * *} \\
(0.00000324)\end{array}$ \\
\hline Population, in million & $\begin{array}{l}2.625^{*} \\
(1.590)\end{array}$ & $\begin{array}{l}2.496^{* *} \\
(1.232)\end{array}$ & $\begin{array}{l}2.394^{* * *} \\
(0.977)\end{array}$ & $\begin{array}{l}2.327^{* * *} \\
(0.831)\end{array}$ & $\begin{array}{l}2.236^{* * * *} \\
(0.689)\end{array}$ & $\begin{array}{l}2.164^{* * * *} \\
(0.647)\end{array}$ & $\frac{2.078^{* * *}}{(0.696)}$ & $\begin{array}{l}2.005^{* *} \\
(0.809)\end{array}$ & $\begin{array}{l}1.942^{* *} \\
(0.940)\end{array}$ \\
\hline Cumulated total financial policies weighted by regulatory quality & $\begin{array}{l}-59.69^{* * *} \\
(25.88)\end{array}$ & $\begin{array}{l}-54.79^{* * *} \\
(20.11)\end{array}$ & $\begin{array}{l}-50.94^{* * *} \\
(15.94)\end{array}$ & $\begin{array}{l}-48.39^{* * * *} \\
(13.60)\end{array}$ & $\begin{array}{c}-44.92^{* * *} \\
(11.33)\end{array}$ & $\begin{array}{l}-42.22^{* * * *} \\
(10.65)\end{array}$ & $\begin{array}{c}-38.95^{* * *} \\
(11.41)\end{array}$ & $\begin{array}{l}-36.16^{* * *} \\
(13.20)\end{array}$ & $\begin{array}{l}-33.78^{* *} \\
(15.31)\end{array}$ \\
\hline Domestic credit to private sector (share of GDP) & $\begin{array}{l}-8.931^{* *} \\
(3.718)\end{array}$ & $\begin{array}{c}-8.318^{* * *} \\
(2.888)\end{array}$ & $\begin{array}{c}-7.835^{* * *} \\
(2.290)\end{array}$ & $\begin{array}{c}-7.515^{* * *} \\
(1.953)\end{array}$ & $\begin{array}{c}-7.082^{* * *} \\
(1.625)\end{array}$ & $\begin{array}{l}-6.743^{* * *} \\
(1.528)\end{array}$ & $\begin{array}{c}-6.333^{* * *} \\
(1.638)\end{array}$ & $\begin{array}{c}-5.985^{* * *} \\
(1.895)\end{array}$ & $\begin{array}{c}-5.686^{* * *} \\
(2.199)\end{array}$ \\
\hline Chim-Ito index & $\begin{array}{l}-69.07 \\
(94.17)\end{array}$ & $\begin{array}{l}-68.98 \\
(73.02)\end{array}$ & $\begin{array}{l}-68.92 \\
(57.89)\end{array}$ & $\begin{array}{l}-68.88 \\
(49.28)\end{array}$ & $\begin{array}{l}-68.82^{*} \\
(40.87)\end{array}$ & $\begin{array}{l}-68.78^{*} \\
(38.40)\end{array}$ & $\begin{array}{l}-68.72^{*} \\
(41.27)\end{array}$ & $\begin{array}{l}-68.68 \\
(47.94)\end{array}$ & $\begin{array}{l}-68.64 \\
(55.69)\end{array}$ \\
\hline Bank Return On Assets (Percentages, After Tax) & $\begin{array}{c}13.40 \\
(46.59)\end{array}$ & $\begin{array}{c}8.809 \\
(36.14)\end{array}$ & $\begin{array}{c}5.190 \\
(28.65)\end{array}$ & $\begin{array}{l}2.798 \\
(24.39)\end{array}$ & $\begin{array}{l}-0.454 \\
(20.25)\end{array}$ & $\begin{array}{l}-2.987 \\
(19.02)\end{array}$ & $\begin{array}{l}-6.063 \\
(20.43)\end{array}$ & $\begin{array}{l}-8.674 \\
(23.72)\end{array}$ & $\begin{array}{l}-10.91 \\
(27.55)\end{array}$ \\
\hline Fossil fuel consumption in TWH per capita & $\begin{array}{l}26.70^{* *} \\
(11.26)\end{array}$ & $\begin{array}{l}25.08^{* * *} \\
(8.741) \\
32\end{array}$ & $\begin{array}{c}23.81^{* * *} \\
(6.929)\end{array}$ & $\begin{array}{c}22.97^{* * *} \\
(5.904) \\
32\end{array}$ & $\begin{array}{c}21.82^{* * *} \\
(4.907)\end{array}$ & $\begin{array}{c}20.93^{* * *} \\
(4.611) \\
3212\end{array}$ & $\begin{array}{c}19.84^{* * *} \\
(4.948) \\
32\end{array}$ & $\begin{array}{c}18.92^{+* *} \\
(5.736)\end{array}$ & $\begin{array}{c}18.14^{* * *} \\
(6.661)\end{array}$ \\
\hline $\mathrm{N}$ & 312 & 312 & 312 & 312 & 312 & 312 & 312 & 312 & 312 \\
\hline
\end{tabular}

Table 15.: Robustness analysis: cumulated stock of policies, accounting for regulatory quality

By focusing on the climate-related financial policies landscape developed between 2000 and 2017, we investigated the determinants of carbon emissions in G20 countries throughout its conditional distribution through the panel quantile regression approach. This method takes the unobserved individual heterogeneity and distributional heterogeneity into consideration. Furthermore, compared with OLS mean regression, the MMQR approach used in the paper allows us to obtain a complete understanding of the factors that affect our sample's carbon emissions distribution.

The empirical results indicate that the impacts of various factors on carbon emission are heterogeneous. First, we find that the implementation of CRFPs reduces $\mathrm{CO}_{2}$ emissions. This result represents a relevant contribution to the existing literature as it emphasizes the existence of a significant relationship between $\mathrm{CO}_{2}$ emissions and climate-related financial policies for the first time. Evidence is provided for recently implemented measures (i.e., those adopted in 2016 and 2017) and policies adopted before 2016. The analysis shows that the older stock of policies has a larger impact on emissions in high emission countries, i.e., those located at the top of the distribution. Regarding more recent policies, they have larger effects on the reduction of $\mathrm{CO}_{2}$ emission in countries in the lower rather than upper quantiles. However, they do not affect the environmental quality in countries located at the 10th quantile, as the coefficient is not significant. Second, in line with existing literature, we find that financial development contributes to improving environmental quality and its impact increases by moving from lower to higher emission countries. Third, further heterogeneity is observed regarding financial openness. We note that the degree of financial openness of a country is associated with environmental degradation, but this is not observed in countries with the highest and lowest emissions. Fourth, our analysis does not support the hypothesis that a financially sound banking system - as proxied by the ROA - is associated with environmental degradation. Finally, our results confirm existing literature regarding the impact of the level of GDP, population and fossil fuel consumption on environmental degradation and the existence of the EKC relationship.

These results are generally robust for alternative model specifications and by considering the direct and indirect effect mechanism. Interestingly, we find that, on the one hand, climate-related financial policies, both long-term and short term have a negative direct (and total) impact on $\mathrm{CO}_{2}$ emissions, thus improving environmental quality. On the other hand, we observe possible positive indirect effects that might imply a worsening of the environmental quality. This positive effect is observed for high emission countries in the presence of short-term policies and low-emission countries in 
the presence of long-term policies.

Based on these empirical results, several important conclusions can be drawn. First, building on the evidence that climate-related financial policies can play a role in the mitigation strategy of G20 countries, they should be more actively promoted at the global level. Second, our study suggests that countries should not also increase the number of measures implemented in this policy area but also aim for specific types of measures to witness improvements in environmental quality. Indeed, our investigation shows that the policies' impact on environmental quality has been larger for quantiles characterized by countries adopting mandatory prudential measures and credit allocation policies. Moreover, this effect has been observed for the older stock of policies. Policies implemented more recently are mostly aimed at defining criteria and guidelines for green banking rather than actively mobilizing green finance; this might explain the smaller impact on $\mathrm{CO}_{2}$ emissions. Third, in our view, the evidence that shows no role - or a smaller role - of CRFPs in the bottom of the $\mathrm{CO}_{2}$ distribution points to the need for a greater engagement of lower emission countries, such as Argentina, Turkey, Australia, in climate-related financial policymaking to achieve their mitigation objectives.

\section{Ethics approval and consent to participate}

Not applicable.

\section{Consent for publication}

Not applicable.

\section{Availability of data and materials}

The datasets used and/or analysed during the current study are available from the corresponding author on reasonable request.

\section{Competing interests}

The authors declare that they have no competing interests.

\section{Funding}

Not applicable.

\section{Authors' contributions}

Conceptualization: PD; Methodology: PD, MD; Formal analysis and investigation: PD, MD; Writing - original draft preparation: PD, MD; Writing - review and editing: PD, MD; Software: MD; Supervision: PD; All authors read and approved the final manuscript. 


\section{Acknowledgements}

The views expressed in this study are those of the authors and do not necessarily represent the views of their affiliated institutions. The authors are responsible for all errors and omissions. 


\section{References}

Acaravci, A. and I. Ozturk (2010). On the relationship between energy consumption, co2 emissions and economic growth in europe. Energy 35(12), 5412-5420.

Acheampong, A. O. (2019). Modelling for insight: does financial development improve environmental quality? Energy Economics 83, 156-179.

Adams, S. and A. O. Acheampong (2019). Reducing carbon emissions: the role of renewable energy and democracy. Journal of Cleaner Production 240, 118245.

Al-Mulali, U., C. N. B. C. Sab, and H. G. Fereidouni (2012). Exploring the bi-directional long run relationship between urbanization, energy consumption, and carbon dioxide emission. Energy 46(1), 156-167.

Alkhathlan, K. and M. Javid (2013). Energy consumption, carbon emissions and economic growth in saudi arabia: An aggregate and disaggregate analysis. Energy Policy 62, 15251532 .

Amel-Zadeh, A. and G. Serafeim (2018). Why and how investors use esg information: Evidence from a global survey. Financial Analysts Journal 74(3), 87-103.

Ameli, N., P. Drummond, A. Bisaro, M. Grubb, and H. Chenet (2019). Climate finance and disclosure for institutional investors: why transparency is not enough. Climatic Change, $1-25$.

Anonymized (2021). Climate-related financial policymaking in the g20: a panel dataset. Data in Brief In press.

Apergis, N. and I. Ozturk (2015). Testing environmental kuznets curve hypothesis in asian countries. Ecological Indicators 52, 16-22.

Apergis, N. and J. E. Payne (2010). The emissions, energy consumption, and growth nexus: evidence from the commonwealth of independent states. Energy policy 38(1), 650-655.

Batten, S., R. Sowerbutts, and M. Tanaka (2016). Let's talk about the weather: the impact of climate change on central banks. Technical report, Bank of England.

Berchin, I. I., S. A. Da Silva, P. Bocquillon, V. H. Fornasari, L. P. C. Ribeiro, J. M. P. Ribeiro, J. B. S. O. de Andrade, et al. (2018). Contributions of public policies to greening sugarcane ethanol production in brazil. In Towards a Sustainable Bioeconomy: Principles, Challenges and Perspectives, pp. 375-393. Springer.

Bhaskaran, R. K., I. W. K. Ting, S. K. Sukumaran, and S. D. Sumod (2020). Environmental, social and governance initiatives and wealth creation for firms: An empirical examination. Managerial and Decision Economics.

Boermans, M. A. and R. Galema (2019). Are pension funds actively decarbonizing their portfolios? Ecological economics 161, 50-60.

Buchner, B. K., P. Oliver, X. Wang, C. Carswell, C. Meattle, and F. Mazza (2017). Global landscape of climate finance 2017. Technical report, Climate Policy Initiative.

Campiglio, E. (2016). Beyond carbon pricing: The role of banking and monetary policy in financing the transition to a low-carbon economy. Ecological Economics 121, 220 - 230.

Campiglio, E., Y. Dafermos, P. Monnin, J. Ryan-Collins, G. Schotten, and M. Tanaka (2018). Climate change challenges for central banks and financial regulators. Nature Climate Change 8(6), 462.

Carney, M. (2015). Breaking the tragedy of the horizon - climate change and financial stability (speech). Bank of England, Speech.

Chenet, H., J. Ryan-Collins, and F. van Lerven (2021). Finance, climate-change and radical uncertainty: Towards a precautionary approach to financial policy. Ecological Economics 183, 106957.

Chinn, M. D. and H. Ito (2010). The chinn-ito index. A de jure measure of financial openness. Online version http://web. pdx. edu/ ${ }^{\sim}$ ito/Chinn-Ito_website. htm, 243-76.

Claessens, S. and E. Feijen (2007). Financial sector development and the millennium development goals. The World Bank.

Coeuré, B. (2018). Monetary policy and climate change, speech by b. coeuré, member of the executive board of the ecb, at a conference on "scaling up green finance: The role of central 
banks". European Central Bank.

COP (2015). Adoption of the paris agreement. UN-Framework Convention on Climate Change.

Dasgupta, P. (2021). The economics of biodiversity: The dasgupta review. London: HM Treasury.

Dasgupta, S., B. Laplante, and N. Mamingi (2001). Pollution and capital markets in developing countries. Journal of Environmental Economics and management 42(3), 310-335.

De Haas, R. and A. A. Popov (2019). Finance and carbon emissions. ECB Working Paper.

Della Croce, R., C. Kaminker, and F. Stewart (2011). The role of pension funds in financing green growth initiatives.

den Elzen, M., T. Kuramochi, N. Höhne, J. Cantzler, K. Esmeijer, H. Fekete, T. Fransen, K. Keramidas, M. Roelfsema, F. Sha, et al. (2019). Are the g20 economies making enough progress to meet their ndc targets? Energy policy 126, 238-250.

D'Este, P., S. Iammarino, M. Savona, and N. von Tunzelmann (2012). What hampers innovation? revealed barriers versus deterring barriers. Research policy 41(2), 482-488.

DNB (2017). Waterproof? an exploration of climate-related risks for the dutch financial sector. De Nederlandsche Bank, working paper.

Dombrovskis, V. (2017). Greening finance for sustainable business. Speech by Vice-President for the Euro and Social Dialogue, Financial Stability and Financial Services Valdis Dombrovskis (SPEECH/17/5235).

Dong, K., G. Hochman, Y. Zhang, R. Sun, H. Li, and H. Liao (2018). Co2 emissions, economic and population growth, and renewable energy: Empirical evidence across regions. Energy Economics 75, 180-192.

D'Orazio, P. and P. Löwenstein (2020). Mobilising investments in renewable energy in germany: which role for public investment banks? Journal of Sustainable Finance \& Investment, 1-24.

D'Orazio, P. and L. Popoyan (2019). Fostering green investments and tackling climate-related financial risks: Which role for macroprudential policies? Ecological Economics 160, 25 - 37.

ECB (2020). Ecb report on institutions' climate-related and environmental risk disclosures. Technical report, European Central Bank - Banking Supervision.

El Ghoul, S., O. Guedhami, C. C. Kwok, and D. R. Mishra (2011). Does corporate social responsibility affect the cost of capital? Journal of Banking ES Finance 35(9), 2388-2406.

Elderson, F. (2018). From mission to supervision: putting sustainable prosperity on the agenda of the dutch central bank. lse sustainable finance leadership series.

Eskander, S. M. and S. Fankhauser (2020). Reduction in greenhouse gas emissions from national climate legislation. Nature Climate Change 10(8), 750-756.

Farhani, S. and I. Ozturk (2015). Causal relationship between co 2 emissions, real gdp, energy consumption, financial development, trade openness, and urbanization in tunisia. Environmental Science and Pollution Research 22(20), 15663-15676.

Fase, M. M. and R. Abma (2003). Financial environment and economic growth in selected asian countries. Journal of Asian economics 14 (1), 11-21.

FT (2020). Christine lagarde wants key role for climate change in ecb review. Technical report, The Financial Times, 27 November 2020.

Galaz, V., J. Gars, F. Moberg, B. Nykvist, and C. Repinski (2015). Why ecologists should care about financial markets. Trends in Ecology \& Evolution 30(10), 571-580.

Geddes, A., T. S. Schmidt, and B. Steffen (2018). The multiple roles of state investment banks in low-carbon energy finance: An analysis of australia, the uk and germany. Energy policy $115,158-170$.

GoI (1998). Act of the republic of indonesia number 7 of 1992 concerning banking as amended by act number 10 of 1998 . Technical report, Government of Indonesia.

Gök, A. (2020). The role of financial development on carbon emissions: a meta regression analysis. Environmental Science and Pollution Research, 1-19.

Grossman, G. M. and A. B. Krueger (1995). Economic growth and the environment. The quarterly journal of economics 110(2), 353-377.

Hafner, S., A. Jones, A. Anger-Kraavi, and J. Pohl (2020). Closing the green finance gap-a systems perspective. Environmental Innovation and Societal Transitions 34, 26-60. 
He, J. and P. Richard (2010). Environmental kuznets curve for co2 in canada. Ecological Economics 69(5), 1083-1093.

Heller, N. E. and E. S. Zavaleta (2009). Biodiversity management in the face of climate change: a review of 22 years of recommendations. Biological conservation 142(1), 14-32.

HLEG (2018). Final report on financing a sustainable european economy. Interim Report High-Level Expert Group on Sustainable Finance.

IEA (2018). World energy investment 2018. Publishing Paris, https://www.iea.org/publications/freepublications/publication/WEIO2014.pdf.

IEA (2020). Global co2 emissions in 2019. International Energy Agency.

IPCC (2014). Climate change 2014: Synthesis report. Technical report, Intergovernmental Panel on Climate Change.

IPCC (2018). Global warming of 1.5 degrees: summary for policymakers. Technical report, Intergovernmental Panel on Climate Change.

Jalil, A. and M. Feridun (2011). The impact of growth, energy and financial development on the environment in china: a cointegration analysis. Energy Economics 33(2), 284-291.

Jebli, M. B., S. B. Youssef, and I. Ozturk (2016). Testing environmental kuznets curve hypothesis: The role of renewable and non-renewable energy consumption and trade in oecd countries. Ecological Indicators 60, 824-831.

Kao, C. (1999). Spurious regression and residual-based tests for cointegration in panel data. Journal of econometrics 90(1), 1-44.

Kaufmann, D., A. Kraay, and M. Mastruzzi (2011). The worldwide governance indicators: Methodology and analytical issues1. Hague journal on the rule of law 3(2), 220-246.

Kelejian, H. H. (1971). Two-stage least squares and econometric systems linear in parameters but nonlinear in the endogenous variables. Journal of the American Statistical Association 66(334), 373-374.

Khan, A. Q., N. Saleem, and S. T. Fatima (2018). Financial development, income inequality, and co 2 emissions in asian countries using stirpat model. Environmental Science and Pollution Research 25(7), 6308-6319.

Kim, D.-H., Y.-C. Wu, and S.-C. Lin (2020). Carbon dioxide emissions and the finance curse. Energy Economics 88, 104788.

Koenker, R. (2004). Quantile regression for longitudinal data. Journal of Multivariate Analysis $91(1), 74-89$.

Krueger, P., Z. Sautner, and L. T. Starks (2020). The importance of climate risks for institutional investors. The Review of Financial Studies 33(3), 1067-1111.

Lane, P. (2019). Climate change and the irish financial system. Bank of Ireland 1.

Lanoie, P. and M. Roy (1997). Can capital markets create incentives for pollution control? The World Bank.

Le Quéré, C., R. M. Andrew, P. Friedlingstein, S. Sitch, J. Hauck, J. Pongratz, P. A. Pickers, J. I. Korsbakken, G. P. Peters, J. G. Canadell, et al. (2018). Global carbon budget 2018. Earth System Science Data 10(4), 2141-2194.

Le Quéré, C., J. I. Korsbakken, C. Wilson, J. Tosun, R. Andrew, R. J. Andres, J. G. Canadell, A. Jordan, G. P. Peters, and D. P. van Vuuren (2019). Drivers of declining co 2 emissions in 18 developed economies. Nature Climate Change 9(3), 213-217.

Lee, J.-M., K.-H. Chen, and C.-H. Cho (2015). The relationship between co2 emissions and financial development: evidence from oecd countries. The Singapore Economic Review 60(05), 1550117.

Li, Y., M. Gong, X.-Y. Zhang, and L. Koh (2018). The impact of environmental, social, and governance disclosure on firm value: The role of ceo power. The British Accounting Review 50(1), 60-75.

Lokuwaduge, C. S. D. S. and K. Heenetigala (2017). Integrating environmental, social and governance (esg) disclosure for a sustainable development: An australian study. Business Strategy and the Environment 26(4), 438-450.

Machado, J. A. and J. S. Silva (2019). Quantiles via moments. Journal of Econometrics 213(1), $145-173$. 
Mazzucato, M. and G. Semieniuk (2018). Financing renewable energy: Who is financing what and why it matters. Technological Forecasting and Social Change 127, 8 - 22.

Meyerson, F. A. (1998). Population, development and global warming: averting the tragedy of the climate commons. Population and environment 19(5), 443-463.

Monnin, P. (2018). Central banks and the transition to a low-carbon economy. Technical report, Discussion note 2018/1. Zurich: Council on Economic Policies.

Nagelkerken, I. and S. D. Connell (2015). Global alteration of ocean ecosystem functioning due to increasing human co2 emissions. Proceedings of the National Academy of Sciences 112(43), 13272-13277.

Nasreen, S., S. Anwar, and I. Ozturk (2017). Financial stability, energy consumption and environmental quality: Evidence from south asian economies. Renewable and Sustainable Energy Reviews 67, 1105-1122.

Ng, A. W. (2018). From sustainability accounting to a green financing system: Institutional legitimacy and market heterogeneity in a global financial centre. Journal of Cleaner Production 195, 585-592.

NGFS (2017). Charter of the central banks and supervisors network for greening system. Network for Greening the Financial System.

NGFS (2019). A call for action - climate change as a source of financial risk, first comprehensive report. Network for Greening the Financial System.

Ozturk, I. and A. Acaravci (2013). The long-run and causal analysis of energy, growth, openness and financial development on carbon emissions in turkey. Energy Economics 36, 262-267.

Pao, H.-T. and C.-M. Tsai (2011). Multivariate granger causality between co2 emissions, energy consumption, fdi (foreign direct investment) and gdp (gross domestic product): evidence from a panel of bric (brazil, russian federation, india, and china) countries. Energy 36(1), 685-693.

Park, Y., F. Meng, and M. A. Baloch (2018). The effect of ict, financial development, growth, and trade openness on co 2 emissions: an empirical analysis. Environmental Science and Pollution Research 25(30), 30708-30719.

Pedroni, P. (2004). Panel cointegration: asymptotic and finite sample properties of pooled time series tests with an application to the ppp hypothesis. Econometric theory, 597-625.

Pesaran, M. H. (2004). General diagnostic tests for cross-sectional dependence in panels. Empirical Economics, 1-38.

Peters, G., R. Andrew, J. Canadell, P. Friedlingstein, R. Jackson, J. Korsbakken, C. Le Quéré, and A. Peregon (2020). Carbon dioxide emissions continue to grow amidst slowly emerging climate policies. Nature Climate Change 10(1), 3-6.

Phillips, P. C. and D. Sul (2003). Dynamic panel estimation and homogeneity testing under cross section dependence. The Econometrics Journal 6(1), 217-259.

Rasoulinezhad, E. and B. Saboori (2018). Panel estimation for renewable and non-renewable energy consumption, economic growth, co 2 emissions, the composite trade intensity, and financial openness of the commonwealth of independent states. Environmental Science and Pollution Research 25(18), 17354-17370.

Rogoff, K. (1999). International institutions for reducing global financial instability. Journal of Economic perspectives 13(4), 21-42.

Sachs, J. D., W. T. Woo, N. Yoshino, and F. Taghizadeh-Hesary (2019). Why is green finance important? ADBI Working Paper 917 (2019).

Sadorsky, P. (2014). The effect of urbanization on co2 emissions in emerging economies. Energy Economics 41, 147-153.

Sahay, R., M. Čihák, P. N'Diaye, and A. Barajas (2015). Rethinking financial deepening: Stability and growth in emerging markets. Revista de Economía Institucional 17(33), 73107.

Scheffer, M., V. Brovkin, and P. M. Cox (2006). Positive feedback between global warming and atmospheric co2 concentration inferred from past climate change. Geophysical research letters 33(10).

Schnabel, I. (2020). When markets fail - the need for collective action in tackling climate 
change speech by isabel schnabel, member of the executive board of the ecb at the european sustainable finance summit, frankfurt am main, 28 september 2020. European Central Bank.

Schoenmaker, D. and R. Van Tilburg (2016). What role for financial supervisors in addressing environmental risks? Comparative Economic Studies 58(3), 317-334.

Scholtens, B. (2017). Why finance should care about ecology. Trends in Ecology \& Evolution 32(7), 500-505.

Shahbaz, M., H. Mallick, M. K. Mahalik, and P. Sadorsky (2016). The role of globalization on the recent evolution of energy demand in india: Implications for sustainable development. Energy Economics 55, 52-68.

Sheraz, M., X. Deyi, J. Ahmed, S. Ullah, and A. Ullah (2021). Moderating the effect of globalization on financial development, energy consumption, human capital, and carbon emissions: evidence from g20 countries. Environmental Science and Pollution Research, $1-19$.

Solomon, S., G.-K. Plattner, R. Knutti, and P. Friedlingstein (2009). Irreversible climate change due to carbon dioxide emissions. Proceedings of the national academy of sciences 106 (6), 1704-1709.

Steckel, J. C., M. Jakob, C. Flachsland, U. Kornek, K. Lessmann, and O. Edenhofer (2017). From climate finance toward sustainable development finance. Wiley Interdisciplinary Reviews: Climate Change 8(1), e437.

Steffen, W., J. Rockström, K. Richardson, T. M. Lenton, C. Folke, D. Liverman, C. P. Summerhayes, A. D. Barnosky, S. E. Cornell, M. Crucifix, et al. (2018). Trajectories of the earth system in the anthropocene. Proceedings of the National Academy of Sciences 115(33), $8252-8259$.

Stern, D. I. (2004). The rise and fall of the environmental kuznets curve. World development 32(8), 1419-1439.

Stern, N. H., S. Peters, V. Bakhshi, A. Bowen, C. Cameron, S. Catovsky, D. Crane, S. Cruickshank, S. Dietz, N. Edmonson, et al. (2006). Stern Review: The economics of climate change, Volume 30. Cambridge University Press Cambridge.

Tamazian, A., J. P. Chousa, and K. C. Vadlamannati (2009). Does higher economic and financial development lead to environmental degradation: evidence from bric countries. Energy policy 37(1), 246-253.

Tamazian, A. and B. B. Rao (2010). Do economic, financial and institutional developments matter for environmental degradation? evidence from transitional economies. Energy economics 32(1), 137-145.

TCFD (2018). Tcfd: 2018 status report. Task Force on Climate-related Financial Disclosures.

Thoma, j., W. C. F. M. A. S. and H. Chenet (2016). Transition risk toolbox: Scenarios, data, and models. 2 Degree Investing Initiative.

Vermeulen, R., E. Schets, M. Lohuis, B. Kölbl, D.-J. Jansen, and W. Heeringa (2019). The heat is on: A framework for measuring financial stress under disruptive energy transition scenarios

Volz, U. (2017). On the role of central banks in enhancing green finance. UN Environment Inquiry Working Paper 17/01.

Wang, F., S. Yang, A. Reisner, and N. Liu (2019). Does green credit policy work in china? the correlation between green credit and corporate environmental information disclosure quality. Sustainability $11(3), 733$.

Wang, H. (2017). New multilateral development banks: Opportunities and challenges for global governance. Global Policy 8(1), 113-118.

Wang, N., H. Zhu, Y. Guo, and C. Peng (2018). The heterogeneous effect of democracy, political globalization, and urbanization on pm2. 5 concentrations in g20 countries: Evidence from panel quantile regression. Journal of cleaner production 194, 54-68.

Wang, Y. and Q. Zhi (2016). The role of green finance in environmental protection: Two aspects of market mechanism and policies. Energy Procedia 104, 311-316.

Wang, Z. and J. Sarkis (2017). Corporate social responsibility governance, outcomes, and financial performance. Journal of Cleaner Production 162, 1607-1616. 
Weidmann, J. (2020). Combating climate change - what central banks can and cannot do? Speech at the European Banking Congress.

Westerlund, J. (2007). Testing for error correction in panel data. Oxford Bulletin of Economics and statistics 69(6), 709-748.

Widyawati, L. (2020). A systematic literature review of socially responsible investment and environmental social governance metrics. Business Strategy and the Environment 29(2), 619-637.

Xing, C., Y. Zhang, and Y. Wang (2020). Do banks value green management in china? the perspective of the green credit policy. Finance Research Letters 35, 101601.

Yadav, R. and G. Pathak (2013). Environmental sustainability through green banking: A study on private and public sector banks in india. OIDA International Journal of Sustainable Development 6(08), 37-48.

Yeh, J.-C. and C.-H. Liao (2017). Impact of population and economic growth on carbon emissions in taiwan using an analytic tool stirpat. Sustainable Environment Research 27(1), 41-48.

You, W.-H., H.-M. Zhu, K. Yu, and C. Peng (2015). Democracy, financial openness, and global carbon dioxide emissions: heterogeneity across existing emission levels. World Development 66, 189-207.

Yu, E. P.-y., B. Van Luu, and C. H. Chen (2020). Greenwashing in environmental, social and governance disclosures. Research in International Business and Finance, 101192.

Zafar, M. W., S. Saud, and F. Hou (2019). The impact of globalization and financial development on environmental quality: evidence from selected countries in the organization for economic co-operation and development (oecd). Environmental Science and Pollution Research 26(13), 13246-13262.

Zaidi, S. A. H., M. W. Zafar, M. Shahbaz, and F. Hou (2019). Dynamic linkages between globalization, financial development and carbon emissions: Evidence from asia pacific economic cooperation countries. Journal of Cleaner Production 228, 533-543.

Zhang, Y.-J. (2011). The impact of financial development on carbon emissions: An empirical analysis in china. Energy policy 39(4), 2197-2203.

Zhou, X. and C. Feng (2017). The impact of environmental regulation on fossil energy consumption in china: Direct and indirect effects. Journal of Cleaner Production 142, 3174-3183.

\section{Appendix A. Additional graphs}



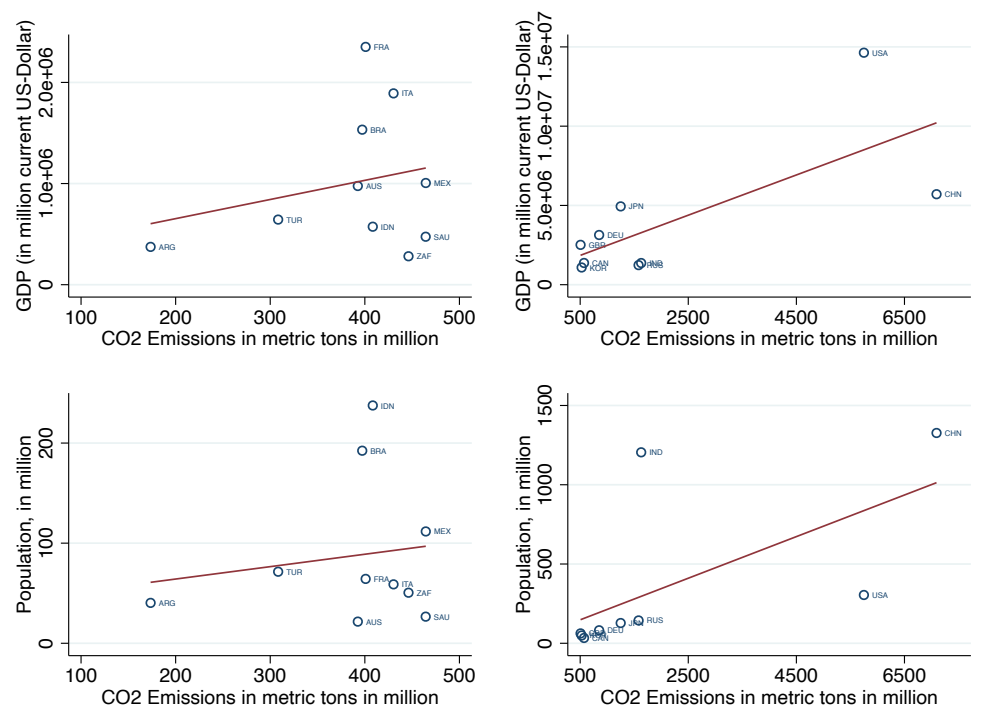

Figure A1.: Average Population, GDP and $\mathrm{CO}_{2}$ emission in G20 by country (2000-2017).
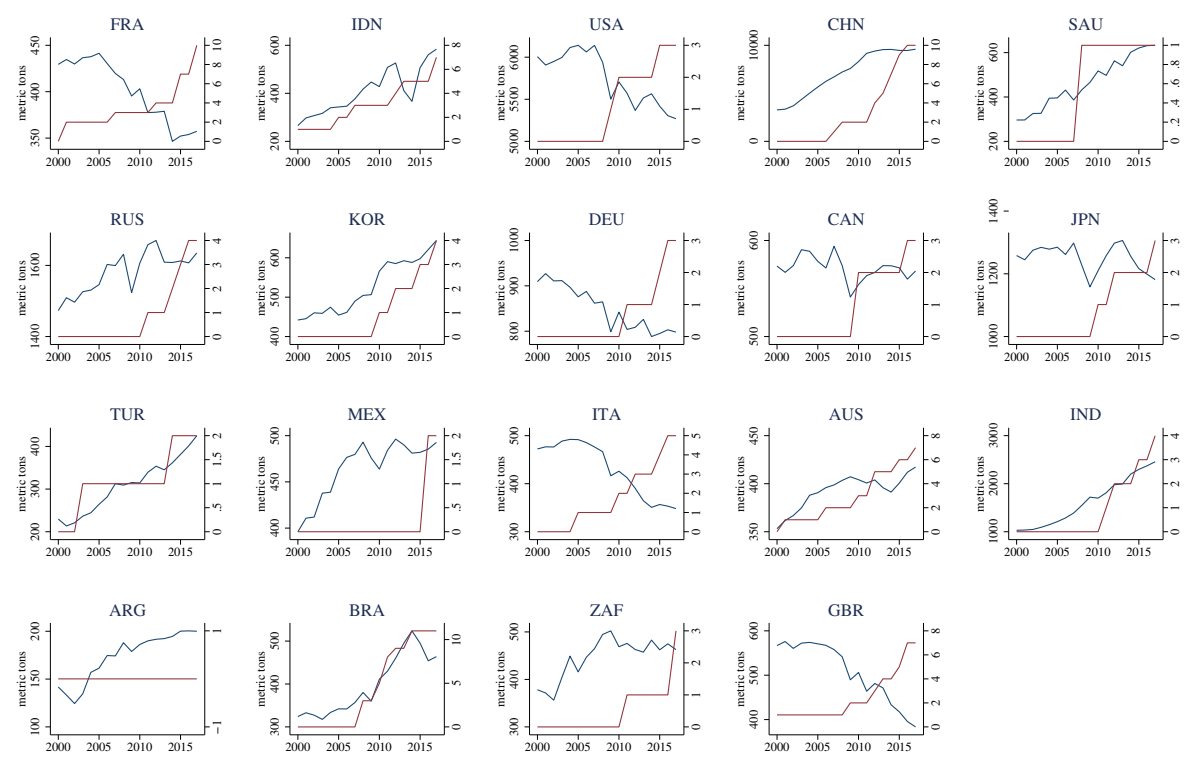

$\mathrm{CO} 2$ emissions

Green financial policies

Figure A2.: $\mathrm{CO}_{2}$ emissions by country and adoption of climate-related financial policies (20002017). 
Figures

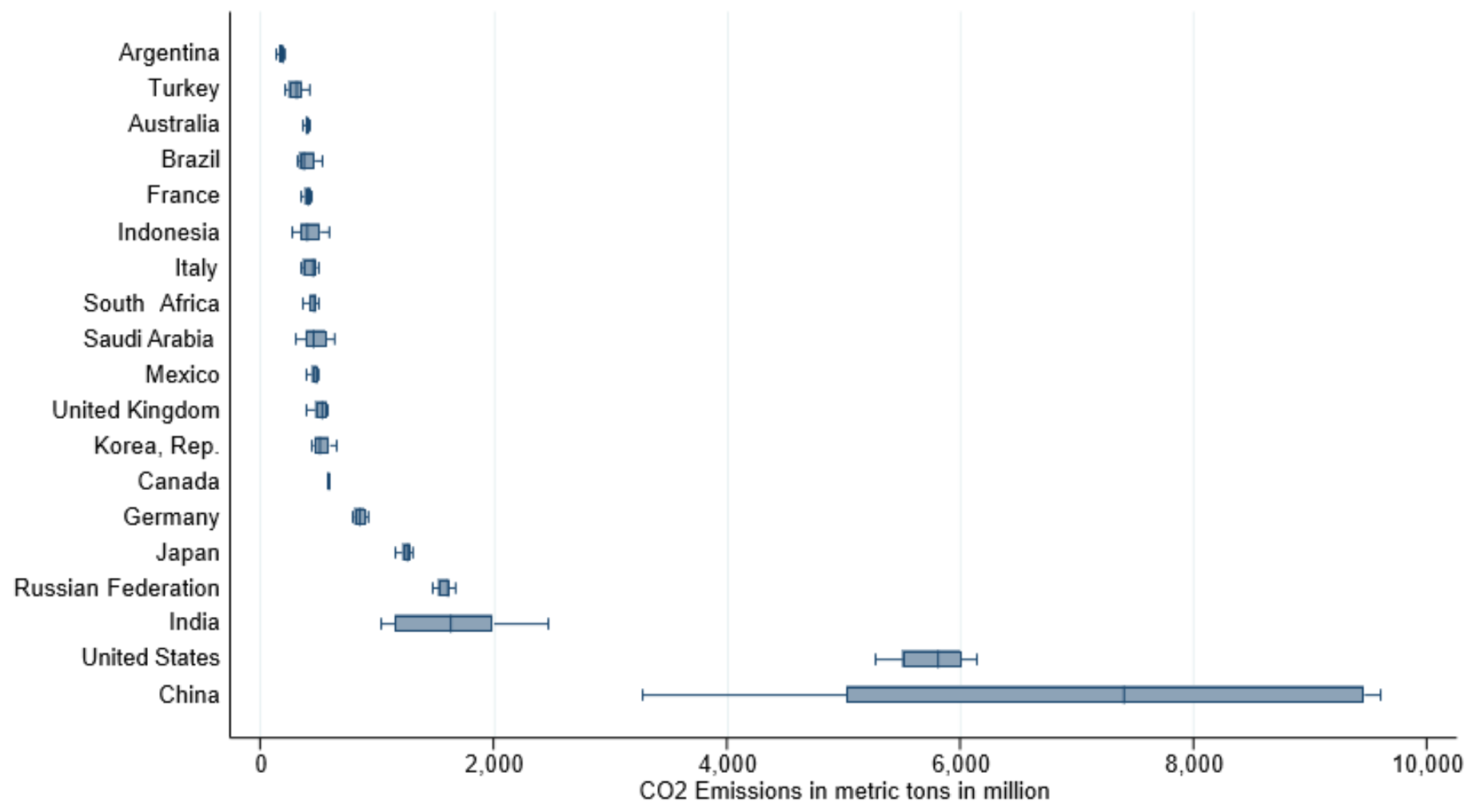

Figure 1

Distribution of CO2 emissions by country (2000-2017). 

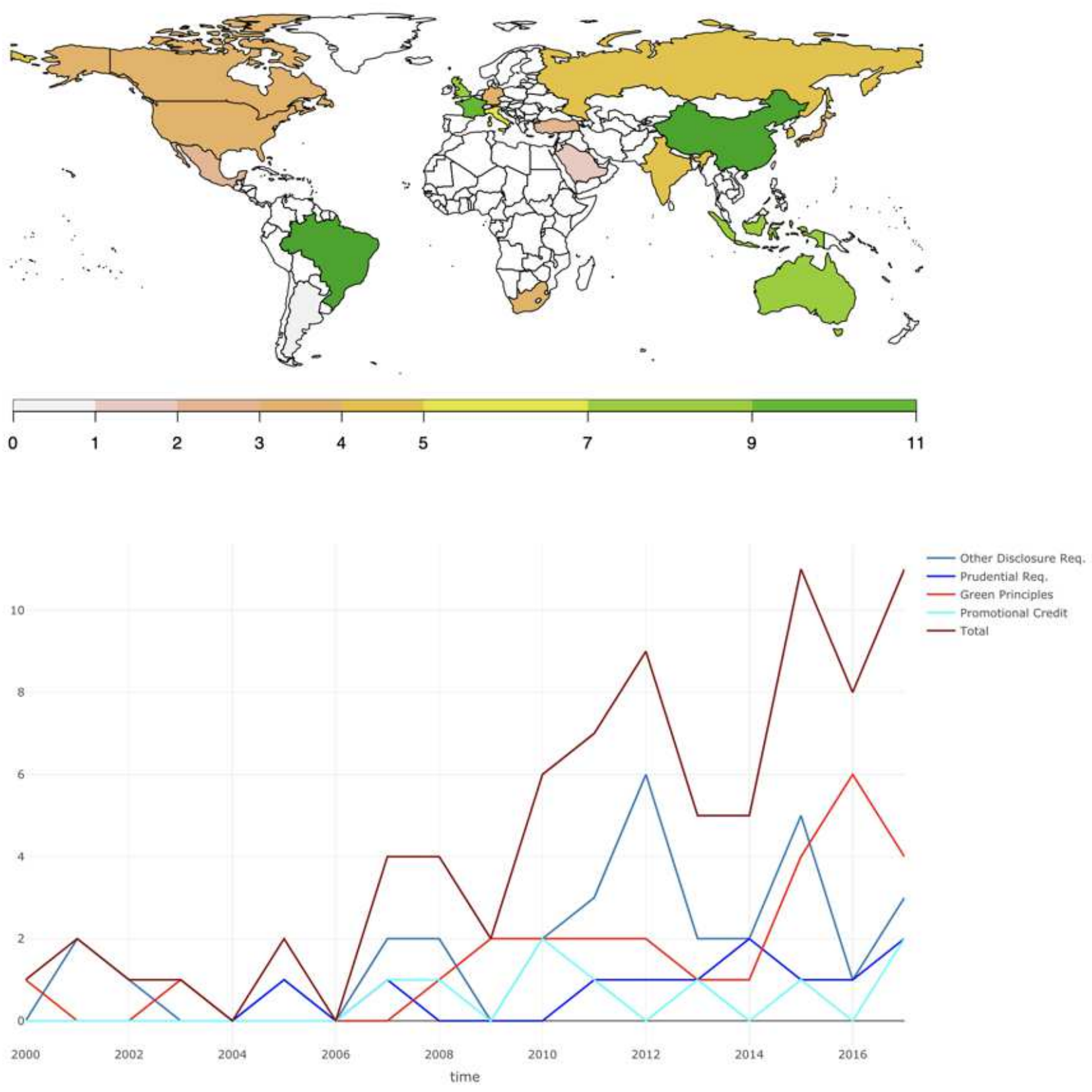

Figure 2

Stock of climate-related financial policies adopted by country at the end of 2017 (top graph). Number of climate-related financial policies adopted per year during 2000-2017 in G20 (bottom graph). Source: authors' elaboration on data retrieved from Anonymized (2021). Note: The designations employed and the presentation of the material on this map do not imply the expression of any opinion whatsoever on the part of Research Square concerning the legal status of any country, territory, city or area or of its authorities, or concerning the delimitation of its frontiers or boundaries. This map has been provided by the authors. 

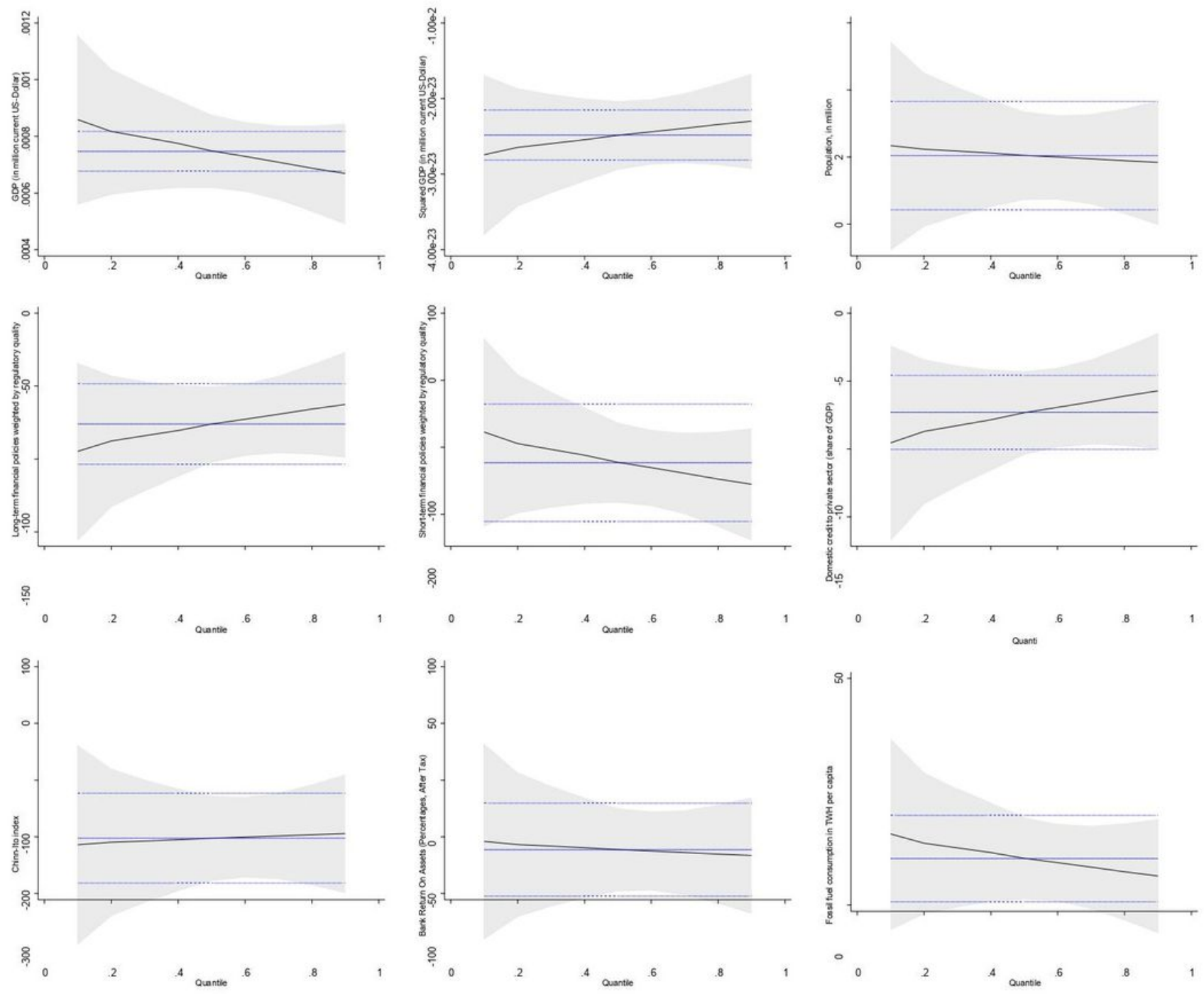

\section{Figure 3}

Method of Moments Panel Quantile Regression results 

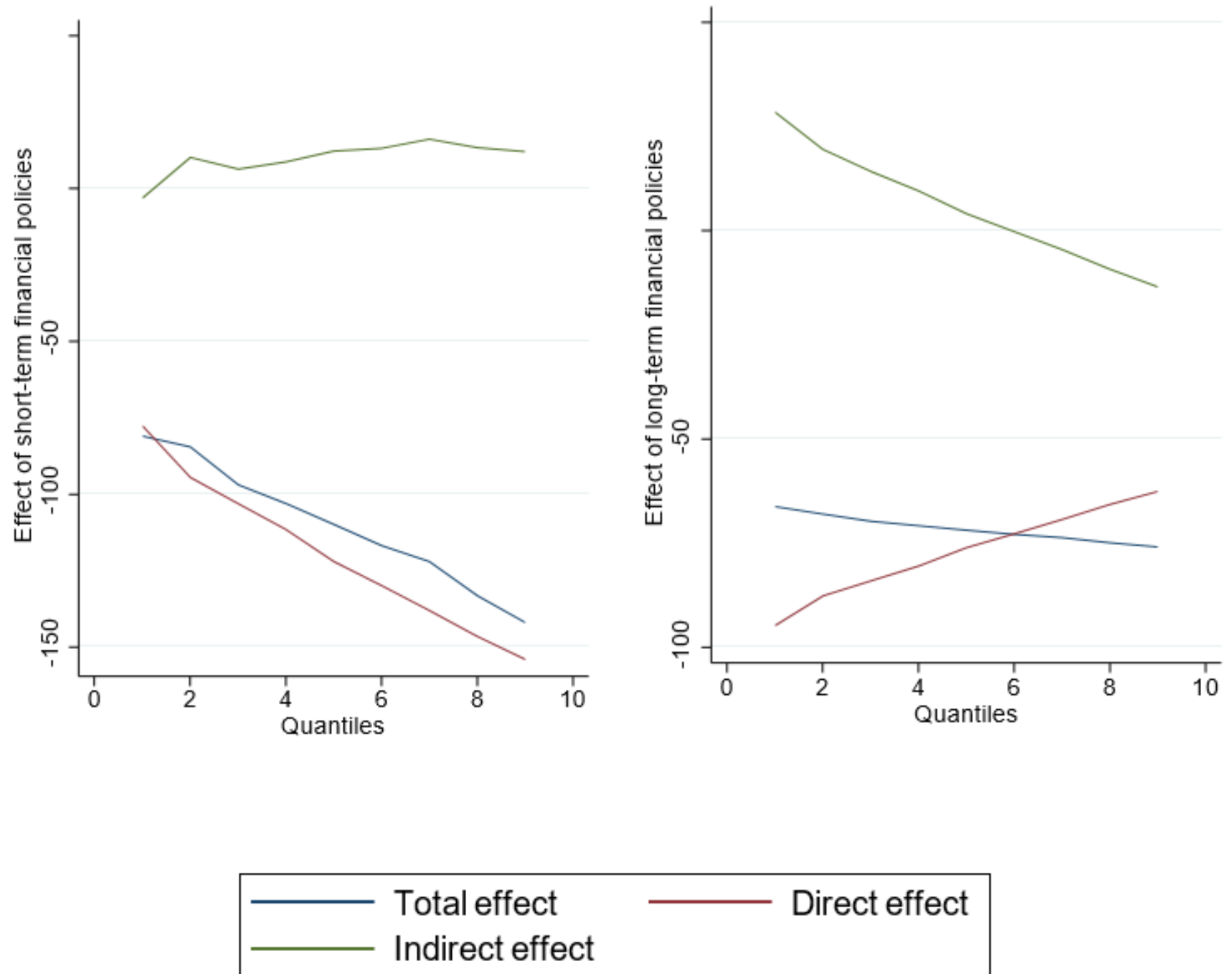

Figure 4

The direct, indirect and total effect of short term (left plot) and long term (right plot) CRFPs on the CO2 distribution

\section{Supplementary Files}

This is a list of supplementary files associated with this preprint. Click to download.

- A1.jpg

- A2.jpg 